\title{
Smart Parasitic Nematodes Use Multifaceted Strategies to Parasitize Plants
}

\begin{abstract}
Muhammad A. Ali ${ }^{1,2 *}$, Farrukh Azeem ${ }^{3}$, Hongjie $\mathrm{Li}^{4}$ and Holger Bohlmann ${ }^{5}$
${ }^{1}$ Department of Plant Pathology, University of Agriculture Faisalabad, Faisalabad, Pakistan, ${ }^{2}$ Centre of Agricultural Biochemistry and Biotechnology, University of Agriculture Faisalabad, Faisalabad, Pakistan, ${ }^{3}$ Department of Bioinformatics and Biotechnology, Government College University, Faisalabad, Pakistan, ${ }^{4}$ National Key Facility for Crop Gene Resources and Genetic Improvement, Institute of Crop Science, Chinese Academy of Agricultural Sciences, Beijing, China, ${ }^{5}$ Division of Plant Protection, Department of Crop Sciences, University of Natural Resources and Life Sciences, Vienna, Vienna, Austria
\end{abstract}

Nematodes are omnipresent in nature including many species which are parasitic to plants and cause enormous economic losses in various crops. During the process of parasitism, sedentary phytonematodes use their stylet to secrete effector proteins into the plant cells to induce the development of specialized feeding structures. These effectors are used by the nematodes to develop compatible interactions with plants, partly by mimicking the expression of host genes. Intensive research is going on to investigate the molecular function of these effector proteins in the plants. In this review, we have summarized which physiological and molecular changes occur when endoparasitic nematodes invade the plant roots and how they develop a successful interaction with plants using the effector proteins. We have also mentioned the host genes which are induced by the nematodes for a compatible interaction. Additionally, we discuss how nematodes modulate the reactive oxygen species (ROS) and RNA silencing pathways in addition to post-translational modifications in their own favor for successful parasitism in plants.

Keywords: PPNs, effector proteins, compatible interaction, molecular parasitism, cyst and root-knot nematodes

\section{INTRODUCTION}

Phytoparasitic nematodes are a serious menace to world's food security. They are biotrophic obligate parasites, whether migratory or sedentary in parasitic behavior (Ali et al., 2017). In both cases they consume the cell sap and plant nutrients during the course of parasitism. Around 4,300 species have been reported as plant parasitic nematodes (PPNs), which account for $7 \%$ of the phylum Nematoda (Decraemer and Hunt, 2006). The sedentary phytoparasitic nematodes develop compatible interactions with a wide range of crop plants including wheat (Triticum aestivum L.), potato (Solanum tuberosum L.), tomato (S. lycopersicum L.), soybean [Glycine max (L.) Merr.] and sugar beet, (Beta vulgaris L.). The worldwide crop losses incurred by parasitic nematodes are estimated to be over 157 million dollars annually (Abad et al., 2008). Cyst and root-knot nematodes belonging to the family Heteroderidae are the most important categories of phytoparasitic nematodes which parasitize a large number of plant species. The root-knot nematode, Meloidogyne incognita (Kofoid and White) Chit. alone infects more than 3,000 plant species including several crop plants (Abad et al., 2008), where nematodes of the genus Meloidogyne induce the development of root galls or knot cells (Jones and Payne, 1978). On the other hand, cyst 
nematodes from genera Heterodera and Globodera establish syncytia in plant roots (Jones, 1981). We have reviewed in detail the physiological and molecular events involved in the development of these nematode feeding sites (NFSs; Ali M. A. et al., 2015).

Since the sequencing of the genome of $M$. incognita (Abad et al., 2008) our understanding has significantly been increased regarding nematode genes and proteins that are involved in successful plant-nematode interactions. Among enormous researches on plant-nematode interactions, a lot of information is available about the genes and proteins that determine nematode virulence (reviewed by Bellafiore and Briggs, 2010). The PPNs have developed several strategies to parasitize plants by using their secretions. These secretions include cell wall degrading enzymes (CWDEs), effectors and proteins involved in mimicry of host proteins for success of nematode establishment on plants (Huang et al., 2003; Bellafiore et al., 2008; Caillaud et al., 2008). The functional roles of various nematode effectors in compatible and incompatible interactions have been reviewed before (Gheysen and Vanmontagu, 1995; Vanholme et al., 2004; Gheysen and Mitchum, 2011; Haegeman et al., 2012; Jaouannet and Rosso, 2013; Kyndt et al., 2013; Mitchum et al., 2013).

PPNs are able to reprogram the expression of plant genes in their own favor using their secretions (Ali M. A. et al., 2015). They are able to induce the expression of genes which are important for their establishment on the plant roots. Nematode induced feeding cells are metabolically hyperactive sites which are the only source of nutrients for the nematodes (Siddique et al., 2009, 2012; Szakasits et al., 2009; Hofmann et al., 2010). On the other hand, nematodes are also able to suppress the expression of defense related genes to avoid resistance responses of their hosts (Gheysen and Fenoll, 2002; Ali M. A. et al., 2015). This review is an update from the most recent literature on how the nematode secretome is involved in establishing successful parasitism in plants and how they manipulate various defense related pathways in plants to avoid resistance responses.

\section{THE NEMATODE SECRETOME CONTAINS A VARIETY OF EFFECTORS}

All PPNs have a unique tool, a needle like structure called stylet, to puncture cell walls and to introduce their secretions into the host plant cells to control the complex parasitism process (Davis et al., 2000). A small proportion of these secretions also come from nematode amphids and cuticle. The proteins secreted by nematodes through the stylet are primarily important for early infection and nematode establishment on the plants; however, these proteins differ significantly in various nematode developmental and parasitic stages (Hussey, 1989; Davis et al., 2000). These secretions are collectively called "secretome" (secreted proteins) of nematodes that results in successful parasitism in plants (Hussey et al., 2002). The effector proteins which are directly or indirectly involved in parasitism are collectively known as "parasitome." Moreover, for parasitic success, the nematodes have evolved in their morphology and physiology, i.e., significant modifications in esophagus at different growth stages (Hussey, 1989; Figure 1).

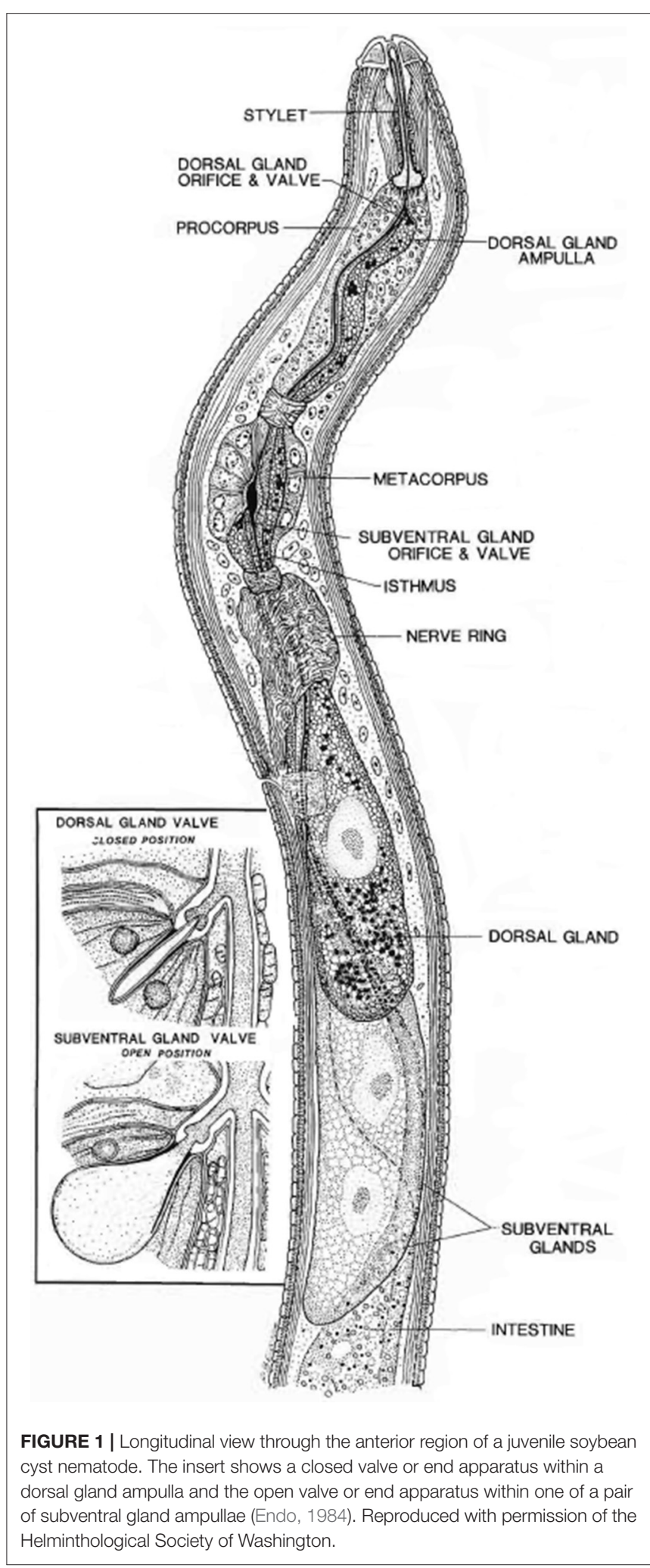


The secretory gland cells of the nematodes are the main source of effector proteins (Figure 1). Both synthesis and secretion of effector proteins are developmentally regulated in the esophageal glands at different parasitic stages of the nematode (Wyss and Zunke, 1986; Davis et al., 2008). It is assumed that the secretions produced by nematodes in their esophageal gland cells induce the differentiation of root cells in the vicinity of vasculature into complex feeding sites (reviewed by Ali M. A. et al., 2015).

The secretomes of sedentary endoparasitic nematodes, especially members of the genera Meloidogyne, Heterodera, and Globodera, are particularly interesting because they induce drastic modifications of gene expression in the parasitized plant cells leading to complex morphological, biochemical, and metabolic changes which turns the parasitized root cells into unique NFSs (Gheysen and Fenoll, 2002). The secretome carries typically a huge volume of highly concentrated proteins; however, the number and amount of various secretory proteins in the matrix may differ with different gland cell types at various developmental stages (Burgess and Kelly, 1987; Vanholme et al., 2004). The sedentary nematodes like root-knot nematodes (RKNs) and cyst nematodes (CNs) deposit their secretions either outside the plasma membrane or inject them straight into the cytoplasm of the recipient cell through their stylet. In both cases, some proteins may mimic the signaling cascade leading to the modification of gene expression of the host cells (Davis and Mitchum, 2005; Mitchum et al., 2013).

Gao et al. (2003) worked out the first comprehensive parasitome profile for the soybean cyst nematode, $H$. glycines Ichinohe. They reported 51 gland-expressed candidate parasitism genes which were previously unidentified. Individual proteins from the parasitome exhibited distinct gland cell expression patterns throughout different parasitic stages (Gao et al., 2003). Furthermore, in the secretome of $M$. incognita 486 secreted proteins were identified. Most of these proteins are homologous to plant proteins, which may be stimulated or induced, and some are effectors which result in the modulation of the plant cell cycle, while others could reprogram the expression of host genes to favor parasitism (Bellafiore et al., 2008). Peng et al. (2013) have explored the host parasitism of the migratory potato rot nematode Ditylenchus destructor Thome by expressed sequence tags (EST) analysis. They reported that 22 ESTs were found similar to effectors reported from other nematodes and most of these effectors were involved in host cell wall degradation and/or modification i.e., 1,4-beta-glucanse, 1,3-betaglucanase, pectate lyase, chitinases, and expansin, however, some of them might be involved in host defense suppression i.e., annexin, calreticulin, and venom allergen-like protein (Peng et al., 2013).

Most parasitism genes encode proteins that contain a signal peptide which targets the protein to the endoplasmic reticulum and through the secretory pathway. Interestingly, some proteins have no signal peptide; for instance, a glutathione-S-transferase (GST) gene which is only expressed in the subventral glands of $\mathrm{J} 3$ and encodes a protein that lacked a signal peptide (Dubreuil et al., 2007). This suggests that the proteins lacking signal peptide could be secreted from parasitic nematodes via different secretory pathways.
The proteins of the secretome include the following categories of effectors:

1. Cell wall degrading enzymes and cell wall loosening proteins which are important for movement through the plant and help piercing the cell walls.

2. Effectors which induce the development of NFSs within the plant and modify the metabolism of these NFSs to establish a compatible interaction.

3. Suppressors that are important to suppress plant resistance responses.

\section{PROTEINS FOR CELL WALL DEGRADATION AND MODIFICATION}

The plant cell wall is the first obstacle faced by PPNs during the course of penetration, infection, and movement into the plant cells. PPNs use their stylet for piercing plant cell walls followed by the secretion of cell wall degrading and modifying enzymes. The structural complication of cell walls is reflected by the variety of CWDEs secreted by PPNs that are able to degrade or change the composition of different structural polysaccharides like cellulose, xylans, hemicellulose, and pectin (Bohlmann and Sobczak, 2014; Wieczorek, 2015). PPNs are different from free living nematodes due to the secretion of CWDEs, which are involved in localized cell wall degradation and modification during the course of infection. These enzymes are very important for movement of nematodes into the plant tissues. Various enzymes are involved in degradation of different carbohydrate polymers which are constituents of the plant cell walls. However, nematodes also use expansins for softening of cell walls for easy movement through the plant tissues. The number of different cell wall degrading and modifying enzymes identified in the genomes of various PPNs is given in Table 1. The most common PPN parasitism genes, which have been extensively studied, code for cellulases or endo-1,4- $\beta$ glucanases. The first cellulase from a nematode was reported at the end of last century (Smant et al., 1998), and after that several studies have shown their occurrence in the secretome of various PPNs (Yan et al., 1998; de Boer et al., 1999; Goellner et al., 2000, 2001; De Meutter et al., 2001; Gao et al., 2002, 2004; Kikuchi et al., 2004; Abad et al., 2008; Haegeman et al., 2008, 2010; Kyndt et al., 2008; Rehman et al., 2009a). The function of these enzymes is to degrade and soften the plant cell walls to facilitate the nematode invasion, migration through the plant tissues and ultimately to establish NFSs (Ali M. A. et al., 2015). Cellulases are comprised of a signal peptide and a catalytic domain; however, in some cases, an additional carbohydrate-binding module (CBM) is also present. The majority of the known endoglucanases belong to the glycosyl hydrolase family 5 (GHF5), while some evolutionary divergent species possess GHF45 [Bursaphelenchus xylophilus (Steiner and Buhrer) Nickle; Kikuchi et al., 2004] and GHF12 endoglucanases [Xiphinema index Thome and Allen (1950); Jones et al., 2005]. Because the proteins coded by endoglucanase genes are very similar to bacterial endoglucanases, it was suggested that these are derived from bacteria through horizontal gene transfer (Jones et al., 2005). Genes coding for another class of enzymes called carbohydrate active enzymes (CAZy) have also 
TABLE 1 | Comparison of predicted cell wall degrading enzymes from the genomes of different nematode species.

\begin{tabular}{|c|c|c|c|c|c|c|c|c|c|}
\hline Nematode species & $\begin{array}{l}\text { Size } \\
(\mathrm{Mb})\end{array}$ & $\begin{array}{c}\text { Gene models } \\
\text { (\#genes) }\end{array}$ & Cellulases & Xylanases & Arabinanases & Pectate lyases & Expasins & Total & References \\
\hline Bursaphelenchus xylophilus & 75 & 18,074 & 11 & 0 & 0 & 15 & 8 & 34 & Kikuchi et al., 2011 \\
\hline Meloidogyneincognita & 86 & 19,212 & 21 & 6 & 2 & 32 & 20 & 81 & Abad et al., 2008 \\
\hline M. hapla & 53 & 13,072 & 6 & 1 & 2 & 24 & 6 & 39 & Opperman et al., 2008 \\
\hline Caenorhabditis elegans & 100 & 20,431 & 0 & 0 & 0 & 0 & 0 & 0 & Consortium, 1998 \\
\hline Pristionchus pacificus & 173 & 24,216 & 7 & 0 & 0 & 0 & 0 & 7 & Dieterich et al., 2008 \\
\hline Bursaphelenchus mucronatus & 96 & 21,252 & 0 & 0 & 0 & 0 & 0 & 0 & Pereira et al., 2013 \\
\hline Globodera pallida & 124.7 & 16,419 & 16 & 6 & 1 & 7 & 9 & 39 & Cotton et al., 2014 \\
\hline Pratylenchus coffeae & 19.67 & 6,712 & 1 & 2 & 2 & 4 & 0 & 9 & Burke et al., 2015 \\
\hline G. rostochiensis & 95.9 & 14,309 & 11 & 0 & 0 & 4 & 3 & 18 & $\begin{array}{l}\text { Eves-Van Den Akker } \\
\text { et al., } 2016\end{array}$ \\
\hline Rotylenchulus reniformis & 37.45 & 10,452 & 11 & 1 & 0 & 2 & 3 & 17 & Nyaku et al., 2014 \\
\hline
\end{tabular}

been identified in nematode species, i.e., Pratylenchus penetrans (Cobb, 1917) Filip. and Stek. 1941, which have probably been horizontally transferred from bacteria (Haegeman et al., 2011). These enzymes are also helpful for the nematodes to develop compatible interactions with the plants.

The expansins are mainly involved in loosening of plant cell walls through a non-enzymatic mechanism that prompts slippage of cellulose microfibrils in the plant cell wall (Sampedro and Cosgrove, 2005). The first functional expansin (Gr-EXPB1) was reported in the golden potato cyst nematode Globodera rostochiensis (Wollenweber) Behrens (Qin et al., 2004; Kudla et al., 2005). They showed that Gr-EXPB1 can disrupt covalent bonds in plant cell walls along with its accompanying ability to loosen non-covalent bonds. Gr-EXPB1 shows similarity with both bacterial and plant expansins. Moreover, it shows highest sequence similarity to two hypothetical proteins from the aerial mycelium-forming soil-inhabiting Actinobacteria and Streptomyces lavendulae. However, the 2nd domain of $\mathrm{Gr}-$ EXPB1 (residues 150-271) showed substantial similarity to a $\beta$-expansin-like protein (PPAL) from Nicotiana tabacum L. and a putative $\beta$-expansin from Arabidopsis thaliana L. (Qin et al., 2004; Kudla et al., 2005). Another expansin-like protein MAP-1 was identified in $M$. arenaria, $M$. incognita, and $M$. javanica. Polyclonal antibodies were produced against MAP1 peptide which strongly labeled J2 amphidial secretions in immunofluorescence microscopy assays, suggesting that MAP1 might have a role in the early steps of plant-nematode interactions (Semblat et al., 2001). Recently, a large MAP1 gene family has been identified in the genus Meloidogyne. The members of this family code for expansin-like proteins which are secreted into plant tissues during parasitism, also thought to function as effectors to stimulate successful root infection (Tomalova et al., 2012). The phylogenetic studies and the distribution of map-1 genes in RKNs further indicated the presence of these genes in species that reproduce by mitotic parthenogenesis (Tomalova et al., 2012). Haegeman et al. (2009) identified a putative expansin like gene (Da-exp1) in the migratory nematode Ditylenchus africanus. Similarly, the transcripts encoding expansin-like proteins were discovered in the transcriptome of $P$. penetrans which showed high similarity with expansin-like genes from $H$. avenae and $H$. glycines (Vieira et al., 2015). However, P. coffeae, which harbors the smallest genome, lacks expansins (Burke et al., 2015). In addition to cell wall modification and softening, an expansin-like protein from G. rostochiensis (GrEXPB2) has shown suppression of cell death induced by NB-LRR proteins in different Nicotiana spp. (Ali S. et al., 2015). Moreover, this protein was found to be involved in the $\mathrm{R}$ genes mediated suppression of immune response in plants, suggesting its role as a negative modulator of nematode parasitism (Ali S. et al., 2015). More recently, an expansin like gene from $H$. avenae ( $H a E X P B 2$ ) has been reported to be involved in compatible interaction as silencing of this gene resulted in reduced $H$. avenae infectivity (Liu et al., 2016).

Pectate lyases or pectinases catalyze the cleavage of internal $\alpha$ 1,4-linkages of pectate by $\beta$-elimination and have a potential role in pectin degradation (Barras et al., 1994). These are classified as polysaccharide lyases and are the members of 5 from 15 families $(1,2,3,9$, and 10) of this type of enzymes (Henrissat, 1991; Henrissat and Davies, 1997). Pectinases are also the part of the nematode parasitomes secreted from the stylet and attack the host cell wall (Davis et al., 2004). These CWDEs are not present in free living, non phytoparasitic nematodes, or any other animals. These are very similar to bacterial pectate lyase proteins, so it is thought that nematodes might have acquired them by horizontal gene transfer (HGT) from bacteria (Jones et al., 2005). Two pectate lyase genes (Bx-pel-1 and Bx-pel-2) were identified and characterized from the pine wood nematode, $B$. xylophilus (Kikuchi et al., 2006). These are expressed solely in the esophageal gland cells of the nematode, showing their secretion into plant tissues to support feeding and migration in the tree. Geric Stare et al. (2011) analyzed the polymorphisms of pectate lyase2 (pel2) gene in the genus Globodera and obtained 78 different pel2 sequences from populations of G. rostochiensis, G. pallida, G. Mexicana, and G. tabacum. It suggests that pectate lyases are widely distributed in this genus and might play an important role in compatible plant-nematode interactions. Similarly, four transcripts were found for polygalacturonases (GH28) in the transcriptome of $P$. penetrans infecting the soybean roots (Vieira 
et al., 2015). Widespread genome and RNAseq sequencing is now uncovering a large number of genes coding for CWDEs. However, sequence similarity is not always a reliable indicator of enzymatic function. The actual function has to be determined with wet lab experiments. Nematode secreted CWDEs along with their subcellular localization and putative function are shown in Table 2. For in depth information please consult the recently developed Nematode CWDE database (Rai et al., 2015).

\section{NEMATODE EFFECTORS MIMIC HOST GENES FOR PARASITIC SUCCESS}

As mentioned in previous sections, sedentary nematodes induce drastic changes in the root cells to create the so-called NFSs known as syncytia or giant cells. These changes are brought about by the secretions of nematodes delivered into the host root cells. In addition to secreting a mixture of CWDEs and related proteins, the most sophisticated parasitic approach of these sedentary parasites involves manipulating the gene expression of the host cell through a set of effector proteins (Davis et al., 2008; Gheysen and Mitchum, 2011). The effector proteins involved in compatible interactions from different PPNs, their sub-cellular localization and putative functions are given in Table 3.

Some effector proteins are involved in molecular mimicry of the host proteins in different ways. Various genes coding for these effectors have been reported to promote nematode parasitism by modulating plant defense pathways. For instance, SPRYSEC effectors (Huang et al., 2006b; Rehman et al., 2009b; Sacco et al., 2009; Postma et al., 2012), CLAVATA3 (CLV3)/ESR (CLE)-like (Wang et al., 2005; Patel et al., 2008; Lu et al., 2009; Wang J. et al., 2010; Wang J. Y. et al., 2010), Mi-EFF1, calreticulin MiCRT, and Hs19C07 are reported for mediating the compatible plant-nematode interactions (reviewed by Ali M. A. et al., 2015).

The nematode effectors are able to target the host proteins directly for compatible plant-nematode interactions by modulating plant defense responses. Chorismate mutases (CM) are regulatory enzymes, involved in host-parasite interaction by mimicking the plant regulatory pathways (Lambert et al., 1999; Doyle and Lambert, 2003; Jones et al., 2003). M. javanica chorismate mutase 1 (MjCM-1) predominantly regulates the auxin pathway by lowering the IAA levels in plant cells by triggering a competition for chorismate metabolism. This results in an alteration of chorismate-derived metabolites and ultimately, in plant cell expansion (Doyle and Lambert, 2003). It was postulated that MjCM-1 may be involved in facilitating nematodes to establish a host-parasite relationship with the plant by manipulating auxin pathways. Very recently, a novel H. schachtii tyrosinase-like effector protein (Hs-Tyr) has been identified (Habash et al., 2017). Hs-Tyr, localized in the nematode esophageal gland, was found to be important for normal infection and establishment of $H$. schachtii on Arabidopsis roots. Tyrosinases are copper monooxygenases that might be involved in the synthesis of phenolic compounds. Expression of Hs-Tyr in Arabidopsis led to changes in the homeostasis of auxin and the ethylene precursor aminocyclopropane-carboxylic acid (Habash et al., 2017).
A variety of CLAVATA/ESR (CLE) peptides inhibit or promote cell differentiation in meristems of the plants; however, this family of signaling peptides is not limited to the plant kingdom but also found in nematodes (Mitchum et al., 2008). These peptides contain highly conserved LxLxxxLILxLLLxS and KRLVPSGPNPLHH motifs that are found both in nematodes and plants (Olsen and Skriver, 2003). The CLE motif sequence of CLE protein from $H$. glycines, HgSYV46, is very similar to that of soybean (G. max) and Vigna angularis (Figure 2). Similarly, CLAVATA/ESR (CLE) peptides from G. rostochiensis and potato and $H$. schachtii and sugar beet fall in the same cluster based on amino acid sequence for CLE motif (Figure 2). This significant sequence and functional similarity between plant and cyst nematode CLEs proposes that the nematode CLEs are potential mimics of repressing cell proliferation and promotion of cell differentiation in plants. This is a key feature in the resemblance of syncytium development with that of xylem differentiation (Fisher and Turner, 2007).

The first CLE gene present in the animal kingdom was identified from the parasitic soybean cyst nematode $H$. glycines and named HgSYV46 (Wang et al., 2005). The encoded protein contains a putative signal sequence at its $\mathrm{N}$ terminus and a 14 AA CLE domain near its C terminus and is specifically expressed within the dorsal esophageal gland cell (Wang et al., 2005; Wang and Fiers, 2009). Four out of five potato cyst nematode CLE genes expressed in esophageal gland cells contain multiple CLE motifs which also have been found in rice, Medicago, and bread wheat multidomain CLE genes (Oelkers et al., 2008; Lu et al., 2009). A G. rostochiensis effector GrCLE1 is processed by host plant proteases and after processing binds directly to the plant CLE receptors CLV2, BAM1, and BAM2 to mimic their function (Guo et al., 2011). Wubben et al. (2015) have described putative CLE genes from Rotylenchulus reniformis (Linford and Oliveira) named $R r$-cle-1, $R r$-cle-2, and $R r$-cle-3 similar to those of Heterodera CLE genes. They suggested that these CLE genes may be involved in governing host specificity, range, and facilitation of syncytium formation. This further advocates that these CLE proteins are involved in the proliferation and differentiation of plants cells during the development of NFSs. Kiyohara and Sawa (2012) reviewed the molecular properties of CLE peptides from plants and nematodes and their modes of action that may provide further insight into plant cell-cell communication, which could also be applied to manipulate plant-nematode interactions.

The RNAi mediated suppression of transcripts of 16D10 effector peptide from $M$. incognita resulted in impaired development of the nematode showing that this gene is important for successful infection and parasitism (Huang et al., 2006a). Similar results have been shown recently, as dsRNA mediated gene silencing of 16D10 effector from $M$. incognita significantly inhibited the infection in transgenic grape hairy roots (Yang et al., 2013). Although, 16D10 from M. incognita is similar to CLE peptides, however, its mode of action is different from the CLE and CLE-like proteins of cyst nematodes. The 16D10 peptide is mostly active in the cytoplasm of infected plant cells compared to uninfected ones via binding to a plant SCARECROWlike transcription factor (Huang et al., 2006b). In planta gene 
TABLE 2 | Cell wall degrading and modifying enzymes secreted by nematodes into the plant roots.

\begin{tabular}{|c|c|c|c|c|}
\hline Gene name & Nematode species & Putative function & Cellular localization & References \\
\hline $\begin{array}{l}\text { Gr-eng-1, Gr-eng-2 and } \\
\text { Hg-eng-1, Hg-eng-2 }\end{array}$ & $\begin{array}{l}\text { Globodera rostochiensis and } \\
\text { Heterodera glycines }\end{array}$ & $\begin{array}{l}\text { Cellulases, } \beta \text {-1,4-endoglucanases } \\
\text { (cellulose digestion, cell wall } \\
\text { degradation, modification, and } \\
\text { intracellular migration) }\end{array}$ & $\begin{array}{l}\text { Subventral gland cells of } \\
\text { second-stage juveniles (J2s) }\end{array}$ & Smant et al., 1998 \\
\hline $\mathrm{Hg}$-eng-2 and $\mathrm{Hg}$-eng-3 & H. glycines & $\begin{array}{l}\beta-1,4-\text {-endoglucanases (cell wall } \\
\text { degradation, modification, and } \\
\text { intracellular migration) }\end{array}$ & Subventral esophageal glands of J2s & Yan et al., 1998 \\
\hline Hg-eng-2-like & H. glycines & $\begin{array}{l}\text { Endoglucanases (cell wall } \\
\text { degradation, modification, and } \\
\text { intracellular migration) }\end{array}$ & Subventral esophageal glands of J2s & Yan et al., 2001 \\
\hline Hg-eng-4 & H. glycines & Endoglucanases & $\begin{array}{l}\text { Subventral gland cells of pre-parasitic } \\
\text { and migratory parasitic second-stage } \\
\text { juvenile }\end{array}$ & Gao et al., 2002 \\
\hline Gt-eng-1 and Gt-eng-2 & G. tabacum & Endoglucanases & Subventral esophageal glands of J2s & Goellner et al., 2000 \\
\hline Da-eng-1 & Ditylenchus africanus & Endoglucanases & Subventral esophageal glands & Kyndt et al., 2008 \\
\hline PC-eng1 & Pratylenchus coffeae & & & \\
\hline Rr-eng-1 & Rotylenchulus reniformis & Endoglucanases & $\begin{array}{l}\text { Expressed in the } \mathrm{J} 2 \text { and adult } \\
\text { vermiform life-stages }\end{array}$ & Wubben et al., 2010 \\
\hline Da-engdel1, 2, 3, and 4 & D. africanus & Endoglucanases & Dorsal or subventral gland cells & $\begin{array}{l}\text { Haegeman et al., } \\
2010\end{array}$ \\
\hline Bx-eng- 1,2 and 3 & Bursaphelenchus xylophilus & Endoglucanases & Esophageal glands & Kikuchi et al., 2004 \\
\hline Da-exp1 & D. africanus & $\begin{array}{l}\text { Expansins loosening and } \\
\text { re-arrangement of plant cell wall } \\
\text { polysaccharides }\end{array}$ & Dorsal or subventral gland cells & $\begin{array}{l}\text { Haegeman et al., } \\
2010\end{array}$ \\
\hline Bx-eng- 1,2 and 3 & B. xylophilus & $\begin{array}{l}\text { Endoglucanases (weakening of the } \\
\text { mechanical strength of the cell walls) }\end{array}$ & Esophageal gland cells & $\begin{array}{l}\text { Shibuya and } \\
\text { Kikuchi, } 2008\end{array}$ \\
\hline gr-ams-1 & G. rostochiensis & $\begin{array}{l}\beta-1,4 \text {, endoglucanases essential for } \\
\text { sense organ function }\end{array}$ & Sheath cells of the amphids & Chen et al., 2005 \\
\hline Mi-eng-1 & M. incognita & $\begin{array}{l}\beta-1,4 \text {, endoglucanases (nematode } \\
\text { specific plant tissue alterations) }\end{array}$ & Esophageal gland cells of J2s & $\begin{array}{l}\text { Rosso et al., 1999; } \\
\text { Béra-Maillet et al., } \\
2000\end{array}$ \\
\hline Hg-eng- 1 and 2 & H. glycines & $\begin{array}{l}\beta-1,4 \text {, endoglucanases (soften the } \\
\text { walls of root cells during penetration } \\
\text { and intracellular migration) }\end{array}$ & $\begin{array}{l}\text { Localized along the juvenile's } \\
\text { migratory path }\end{array}$ & $\begin{array}{l}\text { de Boer et al., 1999; } \\
\text { Wang et al., } 1999\end{array}$ \\
\hline ghf12 & (Xiphinema index) & Endoglucanases from GHF family & & Jones et al., 2005 \\
\hline Gr-exp1, Gr-expB1 & G. rostochiensis & $\begin{array}{l}\text { Expasin (loosens covalent bonds in } \\
\text { plant cell walls) }\end{array}$ & Subventral gland of J2s & $\begin{array}{l}\text { Qin et al., 2004; } \\
\text { Kudla et al., } 2005\end{array}$ \\
\hline Bx-lam-16A & B. xylophilus & $\beta$-1,3-glucanase/cellulase & Oesophageal gland cells & Kikuchi et al., 2005 \\
\hline$B x-p e l-1$ and $B x-p e l-2$ & B. xylophilus & $\begin{array}{l}\text { Pectatelyases (help feeding and } \\
\text { migration) }\end{array}$ & Subventral glands of J2s & $\begin{array}{l}\text { Kikuchi et al., 2004, } \\
2006\end{array}$ \\
\hline Mi-pel-1 and Mi-pel-2 & M. incognita & $\begin{array}{l}\text { Pectatelyases (facilitate the } \\
\text { penetration and intercellular migration } \\
\text { by cell-wall-degradation) }\end{array}$ & Esophageal gland cells of J2s & Huang et al., 2003 \\
\hline Hg-pel-1 & H. glycines & $\begin{array}{l}\text { Pectatelyases (cell-wall-degrading } \\
\text { and migration) }\end{array}$ & Subventral glands of J2s & de Boer et al., 2002 \\
\hline Gr-pel-1 & G. rostochiensis & $\begin{array}{l}\text { Pectatelyases (cell-wall-degrading } \\
\text { and migration) }\end{array}$ & $\begin{array}{l}\text { Subventral oesophageal glands of } \\
\text { J2s }\end{array}$ & Popeijus et al., 2000 \\
\hline Gr-pel-2 & G. rostochiensis & $\begin{array}{l}\text { Pectatelyases (cell-wall-degrading } \\
\text { and migration) }\end{array}$ & $\begin{array}{l}\text { Subventral oesophageal glands of } \\
\text { J2s }\end{array}$ & Kudla et al., 2007 \\
\hline Mi-pe/3 & M. incognita & Cell wall modifications & $\begin{array}{l}\text { J2s subventral oesophageal glands } \\
\text { along their cytoplasmic extensions, } \\
\text { and in the ampullae }\end{array}$ & Vieira et al., 2011 \\
\hline $\begin{array}{l}\text { Polygalacturonases } \\
(\mathrm{GH} 28)\end{array}$ & P. penetrans & Unknown & 2nd stage juveniles & Vieira et al., 2015 \\
\hline HaEXPB2 & H. avenae & $\begin{array}{l}\text { Involvement in successful compatible } \\
\text { interaction }\end{array}$ & J2s subventral oesophageal glands & Liu et al., 2016 \\
\hline
\end{tabular}


TABLE 3 | Nematode effector involved in compatible and incompatible plant-nematode interactions.

\begin{tabular}{|c|c|c|c|c|}
\hline$B x-c r t-1$ & Bursaphelenchus xylophilus & $\begin{array}{l}\text { Calreticulin calcium binding protein, } \\
\text { cell-to-cell trafficking and } \\
\text { differentiation of NF cells. }\end{array}$ & Esophageal gland of J2s & Li et al., 2011 \\
\hline$R s-C R T$ & Radopholus similis & $\begin{array}{l}\text { Essential for the reproduction and } \\
\text { pathogenicity }\end{array}$ & $\begin{array}{l}\text { Oesophageal glands and gonads of } \\
\text { females and males, the intestines of } \\
\text { different juveniles and eggs }\end{array}$ & Li et al., 2015 \\
\hline$B x-v a p-1$ & B. xylophilus & $\begin{array}{l}\text { Venom allergen-like protein (migration } \\
\text { activity of nematodes) }\end{array}$ & Putative esophageal glands of $\mathrm{J} 2 \mathrm{~s}$ & Kang et al., 2012 \\
\hline Mi-vap-2 & Meloidogyne incognita & Venom allergen-like protein & Esophageal Gland of J2s & Wang et al., 2007 \\
\hline Gp-cm-1 & Globodera pallida & $\begin{array}{l}\text { Chorismate mutases accelerates the } \\
\text { conversion of chorismate to } \\
\text { prephenate }\end{array}$ & Subventral gland cells of $\mathrm{J} 2 \mathrm{~s}$ & Jones et al., 2003 \\
\hline$M j-c m-1$ & M. javanica & $\begin{array}{l}\text { Accelerates the conversion of } \\
\text { chorismate to prephenate }\end{array}$ & $\begin{array}{l}\text { Metacorpus and esophageal gland } \\
\text { cells of } \mathrm{J} 2 \mathrm{~s}\end{array}$ & $\begin{array}{l}\text { Lambert et al., } \\
\text { 1999; Doyle and } \\
\text { Lambert, } 2003\end{array}$ \\
\hline$H s-U B / 1$ & Heterodera schachtii & $\begin{array}{l}\text { Ubiquitin extension protein (regulatory } \\
\text { role in NFS formation) }\end{array}$ & Dorsal pharyngeal gland of J2s & Tytgat et al., 2004 \\
\hline $\mathrm{Hg}-\mathrm{chi}-1$ & H. glycines & $\begin{array}{l}\text { Chitinase, accumulates specifically in } \\
\text { later parasitic stages of } H \text {. glycines } \\
\text { (functional roles in the nematode life } \\
\text { cycle) }\end{array}$ & Subventral oesophageal gland cells & Gao et al., 2002 \\
\hline Mi-crt & M. incognita & $\begin{array}{l}\text { Calreticulin, calcium binding protein } \\
\text { (cell-to-cell trafficking and pressure } \\
\text { support), key effector in plant defense } \\
\text { suppression }\end{array}$ & Subventral oesophageal gland region & $\begin{array}{l}\text { Jaubert et al., 2002, } \\
\text { 2005; Jaouannet } \\
\text { et al., } 2012\end{array}$ \\
\hline Mi-msp-1 & $\begin{array}{l}\text { M. incognita, M. arenaria, and } \\
\text { M. javanica }\end{array}$ & $\begin{array}{l}\text { Venom allergen AG5-like gene with } \\
\text { unknown function }\end{array}$ & Parasitic J2s & Ding et al., 2000 \\
\hline Gr-TpX & G. rostochiensis & $\begin{array}{l}\text { Peroxiredoxin-(defense against very } \\
\text { different host responses like ROS) }\end{array}$ & $\begin{array}{l}\text { Nematode surface and material shed } \\
\text { from the surface }\end{array}$ & $\begin{array}{l}\text { Robertson et al., } \\
2000\end{array}$ \\
\hline $\begin{array}{l}\text { CLAVATA3 (CLV3)/ESR } \\
\text { (CLE)-like effector } \\
\text { proteins }\end{array}$ & H. schachtii & $\begin{array}{l}\text { Act as mimics of plant CLE peptides } \\
\text { and are required for successful } \\
\text { nematode infection }\end{array}$ & $\begin{array}{l}\text { Dorsal gland extension and in the } \\
\text { base of the nematode stylet }\end{array}$ & Replogle et al., 2011 \\
\hline $19 C 07$ & H. schachtii & $\begin{array}{l}\text { Effector protein } 19 \mathrm{CO} \text { interacts with } \\
\text { the Arabidopsis auxin influx } \\
\text { transporter LAX3 to control feeding } \\
\text { site development }\end{array}$ & Dorsal gland of all parasitic stages & Lee et al., 2011 \\
\hline Hs4F01 & H. schachtii & $\begin{array}{l}\text { An annexin-like effector may mimic } \\
\text { and interact plant annexin function } \\
\text { during the parasitic interaction }\end{array}$ & $\begin{array}{l}\text { Dorsal oesophageal gland secretory } \\
\text { cell of a third-stage juvenile (J3) }\end{array}$ & Patel et al., 2010 \\
\hline SPRYSEC & G. rostochiensis & $\begin{array}{l}\text { A secreted spry domain-containing } \\
\text { protein (SPRYSEC) binds to the } \\
\text { immune receptor SW5-F } \\
\text { (CC-NB-LRR) to downregulate its } \\
\text { activity }\end{array}$ & Dorsal esophageal gland of J2s & $\begin{array}{l}\text { Rehman et al., } \\
\text { 2009b }\end{array}$ \\
\hline$G p-R b p-1$ & G. pallida & $\begin{array}{l}\text { SPRYSEC protein RBP-1 elicits } \\
\text { Gpa2-and RanGAP2-dependent } \\
\text { plant cell death }\end{array}$ & Dorsal esophageal gland & Sacco et al., 2009 \\
\hline HgCLE1 & H. glycines & $\begin{array}{l}\text { Protein trafficking and host-specific } \\
\text { recognition }\end{array}$ & Ampulla and dorsal gland cells & Wang J. et al., 2010 \\
\hline HsCLE1 and HsCLE2 & H. schachtii & $\begin{array}{l}\text { Mimick target peptides, AtCLEs1-7 } \\
\text { to promote parasitism }\end{array}$ & Dorsal gland cells of J2s & Wang et al., 2011 \\
\hline Gr-CLE-1 Gr-CLE-4 & G. rostochiensis & CLE signaling to facilitate parasitism & $\begin{array}{l}\text { Dorsal gland cells of all parasitic } \\
\text { stages }\end{array}$ & Lu et al., 2009 \\
\hline $\begin{array}{l}\text { Rr-cle-1, Rr-cle-2, and } \\
\text { Rr-cle-3 }\end{array}$ & Rotylenchulus reniformis & $\begin{array}{l}\text { Governing host range and facilitating } \\
\text { syncytium formation }\end{array}$ & Dorsal esophageal gland cell & Wubben et al., 2015 \\
\hline Mj-nulg1a & M. javanica & $\begin{array}{l}\text { Critical for } M \text {. javanica parasitism, } \\
\text { may manipulate nuclear functions of } \\
\text { the host cell }\end{array}$ & $\begin{array}{l}\text { Nuclei of giant cells during nematode } \\
\text { parasitism }\end{array}$ & Lin et al., 2013 \\
\hline Gr-vap1 & G. rostochiensis & $\begin{array}{l}\text { Venom allergen-like effector protein } \\
\text { trigger a defense-related } \\
\text { programmed cell death in tomato } \\
\text { plants harboring Cf- } 2 \text { and Rcr3 }{ }^{\text {pim }}\end{array}$ & $\begin{array}{l}\text { Subventral esophageal gland of } \\
\text { preparasitic J2 }\end{array}$ & $\begin{array}{l}\text { Lozano-Torres et al., } \\
2012\end{array}$ \\
\hline
\end{tabular}


TABLE 3 | Continued

\begin{tabular}{|c|c|c|c|c|}
\hline Mi-eff1 & M. incognita & $\begin{array}{l}\text { M. incognita EFFECTOR- may } \\
\text { manipulate nuclear functions of the } \\
\text { host cell }\end{array}$ & $\begin{array}{l}\text { Dorsal oesophageal gland and } \\
\text { targeted to the nuclei of the NFSs }\end{array}$ & $\begin{array}{l}\text { Jaouannet et al., } \\
2012\end{array}$ \\
\hline$H g-M M P$ & H. glycines & $\begin{array}{l}\text { Metalloproteinases, role in hatching in } \\
\text { other organisms while in cyst } \\
\text { nematodes unknown }\end{array}$ & $\begin{array}{l}\text { Eggs primarily containing fully } \\
\text { developed J2 }\end{array}$ & Kovaleva et al., 2004 \\
\hline map-1 & M. incognita & $\begin{array}{l}\text { Involved in early steps of recognition } \\
\text { between plants and nematodes. }\end{array}$ & Amphidial secretions of the nematode & Semblat et al., 2001 \\
\hline Hg30C02 & H. glycines & $\begin{array}{l}\text { The effector protein interact with a } \\
\text { plant } \beta-1,3 \text {-endoglucanase to } \\
\text { suppress host defense and promote } \\
\text { parasitism }\end{array}$ & $\begin{array}{l}\text { Single enlarged dorsal oesophageal } \\
\text { gland cell of J3 stage }\end{array}$ & $\begin{array}{l}\text { Hamamouch et al., } \\
2012\end{array}$ \\
\hline Hs30C02 & H. schachtii & $\begin{array}{l}\text { Interact with a plant } \\
\beta-1,3 \text {-endoglucanase to suppress } \\
\text { host defense and promote parasitism }\end{array}$ & $\begin{array}{l}\text { Targeted for secretion outside the } \\
\text { nematode gland cell into plant cells }\end{array}$ & $\begin{array}{l}\text { Hamamouch et al., } \\
2012\end{array}$ \\
\hline MiTPI & M. incognita & Triosephosphateisomerase-unknown & Subventral oesophageal glands & Bellafiore et al., 2008 \\
\hline$R s-t t l-1$ to -4 & Radopholus similis & Transthyretin-like genes-unknown & $\begin{array}{l}\text { Rs-ttl-1 (the tissues around the vulva), } \\
\text { Rs-ttl-2 (the ventral nerve cord) }\end{array}$ & Jacob et al., 2007 \\
\hline Mi-gsts-1 & M. incognita & $\begin{array}{l}\text { Glutathione-stransferases (GSTs)- } \\
\text { may be required for correct nematode } \\
\text { development after gall formation }\end{array}$ & $\begin{array}{l}\text { Subventral glands of } \mathrm{J} 2 \text { and } \mathrm{J} 3 \\
\text { stages }\end{array}$ & Dubreuil et al., 2007 \\
\hline Hs-syv46 & H. schachtii & $\begin{array}{l}\text { CLE-like gene- important for } \\
\text { parasitism }\end{array}$ & $\begin{array}{l}\text { Dorsal oesophageal gland cell of } \\
\text { parasitic life stages }\end{array}$ & Patel et al., 2008 \\
\hline Hg-syv46 & H. glycines & $\begin{array}{l}\text { Functional similarity of } \mathrm{Hg} \text {-syv46 to } \\
\text { plant-secreted CLE ligands that may } \\
\text { be required for differentiation of NFSs }\end{array}$ & $\begin{array}{l}\text { Dorsal oesophageal gland cell of } \\
\text { parasitic life stages }\end{array}$ & Wang et al., 2005 \\
\hline Mi-asp2 & M. incognita & $\begin{array}{l}\text { Encodes an active aspartic protease, } \\
\text { a role for the protein in pre-digestion } \\
\text { of peptidic nutrients is unlikely since } \\
\text { J2s do not feed during migration }\end{array}$ & Subventral glands of J2 stage & Vieira et al., 2011 \\
\hline Mi 6D4 & M. incognita & Unknown & $\begin{array}{l}\text { Both the subventral and dorsal glands } \\
\text { of parasitic stages }\end{array}$ & Davis et al., 1992 \\
\hline$H g-g p$ & H. glycines & $\begin{array}{l}\text { RNAi silencing of this gene disrupts } \\
\text { both normal rates of parasite } \\
\text { establishment and sexual fate }\end{array}$ & Single dorsal gland cell only & Bakhetia et al., 2007 \\
\hline MhTTL2 & M. hapla & $\begin{array}{l}\text { Putative role in nematode nervous } \\
\text { system during parasitism }\end{array}$ & Amphids & Gleason et al., 2017 \\
\hline Mh265 & M. hapla & $\begin{array}{l}\text { Modulation of plant basal immune } \\
\text { responses }\end{array}$ & Subventral esophageal gland cells & Gleason et al., 2017 \\
\hline MgGPP & M. graminicola & $\begin{array}{l}\text { RNAi silencing resulted in } \\
\text { substantially increases the resistance } \\
\text { of rice to } M \text {. graminicola }\end{array}$ & Subventral esophageal gland cells & Chen et al., 2017 \\
\hline
\end{tabular}

silencing using RNAi of the 16D10 effector gene established broad resistance in potato against all Meloidogyne species (Dinh et al., 2015). However, suppression of 16D10 transcripts did not interfere with attraction and invasion of $M$. incognita secondstage juveniles toward potato roots. This suggests that $16 \mathrm{D} 10$ peptide is important for post invasion success of $M$. incognita on potato roots.

Using the yeast two-hybrid assay, a direct interaction was found between 10A06 effector peptide and a plant spermidine synthase 2 (SPDS2), an enzyme involved in polyamine (spermidine) synthesis in plants (Hewezi et al., 2010). This interaction resulted in an elevated amount of SPDS2 protein in the infected plant cells. This brings about morphophysiological changes in the cell caused by an altered amount of polyamines. Additionally, the enhanced antioxidant protection and disruption of SA signaling are key features modulated by nematode effector 10 A06 (Hewezi et al., 2010). Similarly, the cyst nematode effector protein, 30C02 specifically interacts with Arabidopsis $\beta$-1,3-endoglucanase (At4g16260) to promote successful parasitism. This was confirmed by in planta silencing of 30C02 that led to up-regulation of At4g16260 which in turn significantly decreased nematode infection on Arabidopsis roots (Hamamouch et al., 2012). Likewise, a newly identified effector protein from $M$. incognita (Mi-EFF1) is targeted to nuclei of the NFSs where it possibly manipulates the nuclear functions of the host cell (Jaouannet et al., 2012). However, the exact molecular function of Mi-EFF1 is still unknown. A similar novel nematode effector protein, MJ-NULGla that is targeted to giant cell nuclei and plays a critical role in $M$. javanica has been found recently (Lin et al., 2013). But the exact function 


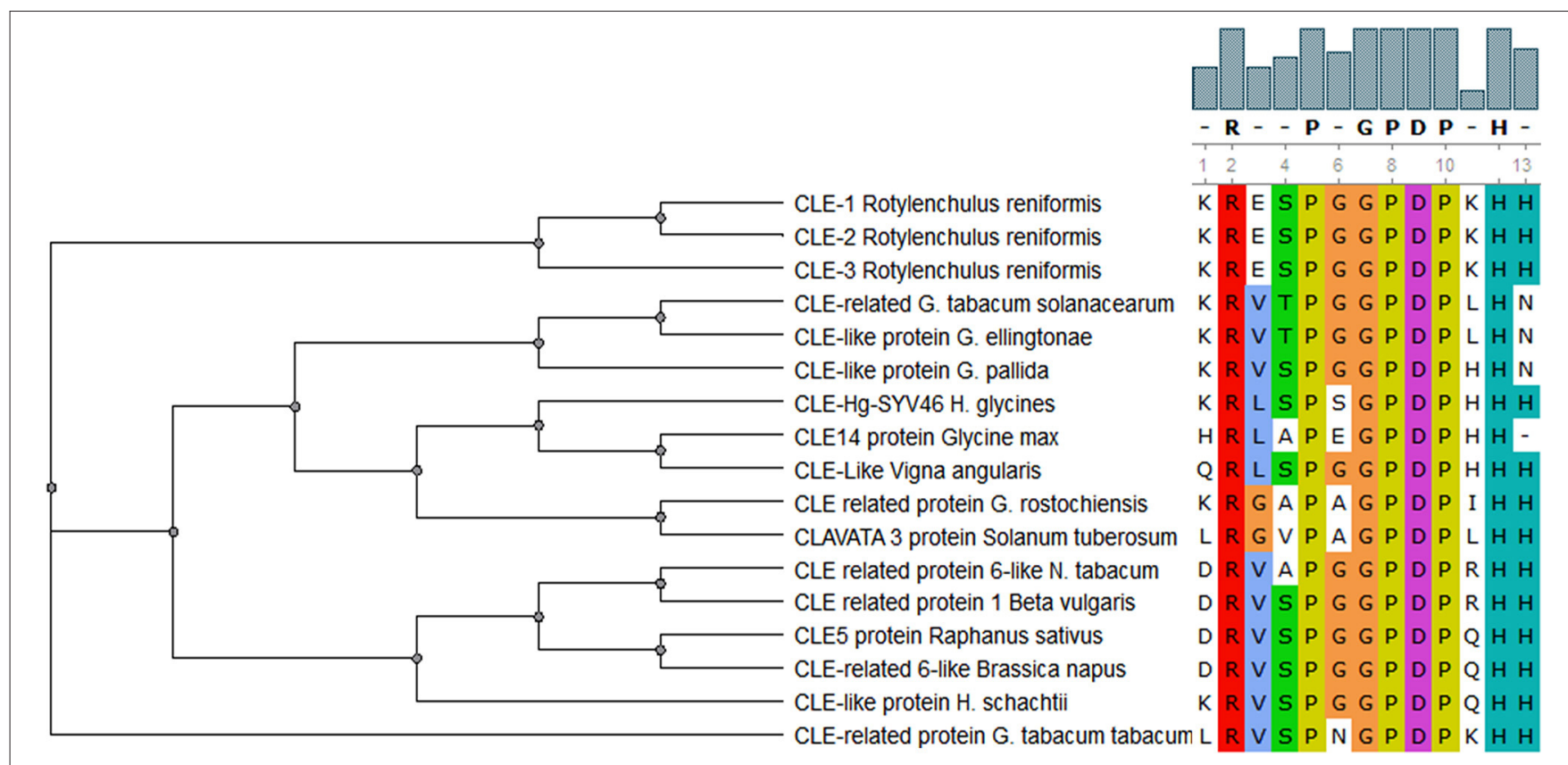

FIGURE 2 | Comparison of CLE motif in CLAVATA/ESR (CLE) peptides from different PPNs and plant species. This demonstrates highly conserved amino acid residues in this motif with six substitutions in total (one, two, or three). It reads xRxxPxGPDPxHx at 95\% level of similarity cutoff.

of this protein remains elusive. Another root-knot nematode calreticulin Mi-CRT, secreted in the apoplasm by the nematode, is demonstrated as a key effector involved in plant basal defense suppression by down-regulation of genes involved in defense responses of the plants (Jaubert et al., 2002, 2005; Jaouannet et al., 2013). The overexpression of Mi-CRT in Arabidopsis has resulted in suppression of the induction of defense related genes and callose deposition after treatment with the PAMP elf18 (Jaouannet et al., 2013). Similarly, a calcium binding calreticulin protein (Bx-crt-1) expressed in the esophageal gland of $B$. xylophilus has been found to be involved in cell-to-cell trafficking and differentiation of nematode feedings cells thus helping the nematodes for the establishment on the plants (Li et al., 2011). Moreover, a calreticulin ( $R s-C R T)$ from the migratory nematode Radopholus similis [(Cobb, 1893) Thorne, 1949] expressed in esophageal glands and gonads of females and males, the intestines of different juveniles and eggs was found essential for the reproduction and pathogenicity in tomato roots (Li et al., 2015). This demonstrates that silencing of calreticulin genes could be used as potential tool for the development of transgenic plants with enhanced resistance against both sedentary and migratory PPNs.

A nematode secreted ANNEXIN like gene (Hs4F01) from $H$. schachtii showing functional similarity to plant annexin has been added to the expanding list of molecular mimics secreted by nematodes (Patel et al., 2010). The annexins bind calcium and phospholipids and are involved in a variety of cellular and physiological processes associated with abiotic stress responses in plants. Hs4F01 annexin-like effector secreted into host root cells may mimic plant annexin function during the parasitic interaction (Patel et al., 2010). A recent study has shown that the cereal cyst nematode $H$. avenae annexin like protein (Ha-annexin) is localized in the nucleus of plant cells and suppresses plant defense (Chen C. et al., 2015). A transgenic wheat line containing a host induced gene silencing construct revealed impaired nematode development. Moreover, transient expression of Ha-annexin resulted in suppression of the host hypersensitive response triggered by BAX protein and various pathogen associated molecular patterns (PAMPs) such as flagellin (Chen C. et al., 2015). It is proposed that this protein binds with the promoters of the defense related genes to suppress the transcription of these genes for infection and parasitic success.

The development of nematode feeding cells is highly associated with auxin accumulation in the NFSs (Grunewald et al., 2009). Sugar beet cyst nematode, H. schachtii, effector protein 19C07 has the ability to bind to an auxin transporter LAX3 in Arabidopsis to control NFS development by modulating auxin influx in syncytia (Lee et al., 2011). Auxin and cytokinin trigger the development and proliferation of protophloem around the giant cells and metaphloem around the syncytia (Absmanner et al., 2013). However, MjCM-1 is proposed to lower the IAA level in plant cells by triggering a competition for chorismate that leads to an alteration of chorismatederived metabolites which, in turn, ultimately results in plant cell expansion allowing nematodes to establish a compatible interaction with the plants (Doyle and Lambert, 2003). Similarly, cytokinins are very important hormones for successful development of NFSs. In a recent study, cytokinin deficient mutants of Arabidopsis resulted in reduced susceptibility against beet cyst nematode (Siddique et al., 2015). It was also observed that $H$. schachtii contains a cytokinin-synthesizing isopentenyltransferase gene which modulates virulence, cell 
division in plant root and establishment of syncytia in Arabidopsis.

Hyper-Variable Apoplastic (HYP) effector genes belong to a novel gene family which was discovered in G. pallida. These are organized in three different subfamilies and the encoded proteins contain subfamily specific tandem repeats at the $\mathrm{C}$-terminus. The genes are expressed in amphidial sheath cells while the proteins were found at the interface between plant and nematode, between the nematode and the syncytial cell wall. HYP effectors were also identified in other cyst nematodes but not in Meloidogyne species. How these effectors operate is not yet known but the members of this family ( $G p-h y p)$ were found to be important for the development of nematode susceptibility in potato hairy roots (Eves-van den Akker et al., 2014).

Some effector proteins are targeted to the nuclei of the plant cells to reprogram the expression of various plant genes. A $M$. incognita effector protein (7H08) was found to be imported into the nuclei of plant cells after being delivered by the nematode into giant cells. According to the authors, this was the first report of a nematode effector that has transcriptional activation ability in the plant nucleus (Zhang et al., 2015). It depicts that nematode effectors can act as transcription factors to regulate the expression of plant genes.

A recent study revealed that $M$. graminicola effector, MgGPP, is exclusively expressed in subventral esophageal gland cells and up-regulated in 2nd stage juveniles (Chen et al., 2017). Based upon RNAi silencing and overexpression studies of MgGPP, it was reported that MgGPP is required for a successful nematode parasitism in rice. N-glycosylation of MgGPP was found to be essential for suppression of the host resistance response. Most of the effector proteins are reported to be active in the early stages of PPNs. However, an effector gene, Misp12, has been found in $M$. incognita to be involved in later stages of parasitism on plant roots (Figure 3; Xie et al., 2016). In planta virus-induced RNA silencing of this effector gene resulted in a significant decrease of parasitic ability of M. incognita. Suppression of Misp12 resulted in up-regulation of defense related genes of jasmonic acid (JA) and salicylic acid (SA) pathways, while overexpression of Misp12 promoted down-regulation of genes involved in SA pathway. This suggests that Misp12 is associated with the suppression of defense response of the plants.

Other nematode effector proteins can disarm resistance proteins deployed by the plants. It has been shown that the pinewood nematode B. xylophilus employs a multilayered detoxifying approach by using various effectors in a systematic way for protection against host defense responses during the infection process (Espada et al., 2016).

Similarly, a M. incognita effector protein MiMsp40 was found to be important for nematode parasitism on Arabidopsis roots (Niu et al., 2016). The overexpression and silencing of MiMsp40 in Arabidopsis demonstrated nematode success and suppression, respectively, which was coupled with reduction in callose deposition and elf18-triggered immunity. Moreover, its transient expression revealed inhibition in Bax-triggered defense-related programmed cell death and Effector Triggered Immunity (ETI) cognate elicitors R3a/Avr3a. This proposed that this novel effector is very vital for the suppression of both Pattern

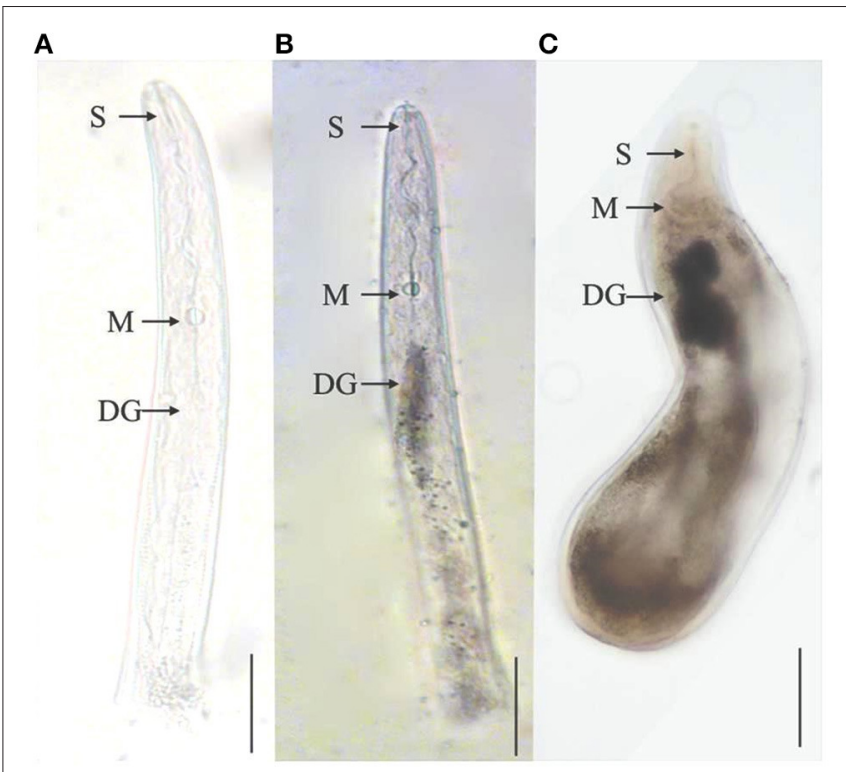

FIGURE 3 | Localization of effector protein Misp12 in different parasitic stages of M. incognita. (A) The sense Misp12 DIG-labeled cDNA probes as a negative control in parasitic second-stage juveniles. $(\mathbf{B}, \mathbf{C})$ Misp12 is localized in the dorsal esophageal gland (DG) of parasitic 2nd stage juveniles and females. The DG, metacorpus (M), and stylet (S) are indicated with arrows. Scale bar = $50 \mu \mathrm{m}$. The figure is reproduced from Xie et al. (2016) with permission from the authors.

Triggered Immunity (PTI) and ETI mediated plant defenses to facilitate nematode parasitism (Niu et al., 2016).

\section{EFFECTORS UNCOVERED BY THE PLANT RESISTANCE SYSTEM}

If effectors are recognized by the plant resistance system, especially R proteins, they are called avirulence (Avr) proteins and their recognition, either directly or indirectly, leads to ETI. There are several examples of nematode proteins which act as Avr proteins for conferring gene-for-gene resistance to the host plants. Some of these nematode effectors lead to resistance responses in plants. MiCg-1 (Gleason et al., 2008), $\mathrm{Hg}-\mathrm{cm}-1$ (Bekal et al., 2003; Lambert et al., 2005; Castagnone-Sereno et al., 2009), MiMAP-1.2 (Castagnone-Sereno et al., 2009), Gp-Rbp-1 (Blanchard et al., 2005; Sacco et al., 2009), Gr-VAP1 (LozanoTorres et al., 2012), and SPRYSEC-19 (Rehman et al., 2009b; Postma et al., 2012) are some important examples of nematode effectors which are involved in incompatible plant-nematode interactions.

The MiMAP-1.2 protein secreted by $M$. incognita was specifically expressed in lines avirulent on $\mathrm{Mi}-1$ resistant tomato plants (Semblat et al., 2001; Castagnone-Sereno et al., 2009). A similar behavior was shown by $\mathrm{Hg}-\mathrm{CM}-1$ protein against soybean cultivars. However, the corresponding resistance genes for these candidate $A v r$ genes and their particular functions are still unknown (Bekal et al., 2003; Lambert et al., 2005). Another gene $(\mathrm{Cg}-1)$ from $\mathrm{M}$. incognita was also described as 
an Avr gene against the $\mathrm{Mi}-1$ gene in tomato (Gleason et al., 2008). This was confirmed by soaking the nematode juveniles of M. incognita Mi-1-avirulent strain in dsRNA corresponding to part of the predicted $C g-1$ transcript. This resulted in virulence of these juveniles on tomato carrying the $M i-1$ gene, strongly suggesting that $\mathrm{Cg}-1$ expression in the nematode is required for $M i-1$-mediated resistance.

Members of the SPRYSEC family were also found to be involved in incompatible plant-nematode interaction (Rehman et al., 2009b). The SPRYSEC-19 gene has been isolated from $G$. rostochiensis, the protein of which interacts with the LRR region of a novel CC-NBS-LRR protein (SW5-F) that corresponds to a resistance gene cluster similar to the SW5 family. However, SPRYSEC-19 did not trigger a hypersensitive response in tobacco leaves when it was transiently co-expressed with the SW5-F protein (Postma et al., 2012). In contrast, another SPRYSEC member (Gp-Rbp-1) isolated from G. pallida elicits a hypersensitive response when co-expressed with Gpa2, a potato resistance protein, and Ran GTPase Activating Protein 2 (RanGAP2) (Blanchard et al., 2005; Sacco et al., 2009). The variability of potato RanGAP2, on one hand does not affect the recognition of Gpa2; however, on the other hand it enhances the activity of Gpa2 to boost the defense response in potato plants. This suggests that the nematode effector Gp-Rbp-1 is the prime cause of the evolution of RanGAP2 locus in potato as compared to Gpa2 resistance gene (Carpentier et al., 2013). The genome of G. pallida contains 299 genes predicted to have one or more SPRY domains, showing a great expansion of this gene family in the white potato cyst nematode as compared to other PPNs (Cotton et al., 2014). The diversity of SPRY domain containing genes in $G$. pallida demonstrates that they might be involved in a wide range of functions, including compatible and incompatible interactions with the host plants. Several SPRYSEC genes are differentially expressed between J2s infecting the susceptible cultivar and those infecting the partially resistant lines in potato (Rehman et al., 2009b; Postma et al., 2012).

The venom allergen-like protein (Vap) family is also interesting because of increased transcription of its members during plant infection (Ding et al., 2000; Wang et al., 2007; Kang et al., 2012; Lozano-Torres et al., 2012). An effector protein (venom allergen-like protein Gr-Vap1) was found in $G$. rostochiensis which is reported to interact with the apoplastic cysteine protease Rcr3 $3^{\text {pim }}$ of tomato (Lozano-Torres et al., 2012). In tomato plants containing the resistance gene Cf-2, originally identified as a resistance gene against Cladosporium fulvum, this interaction of Gr-Vap1 with Rcr3 $3^{\text {pim }}$ triggers defense-related programmed cell death and resistance to $G$. rostochiensis. VAP proteins from $H$. schachtii when expressed in Arabidopsis induced susceptibility to this nematode but also to unrelated pathogens. It is thought that VAP proteins interact with extracellular papain-like cysteine proteases to suppress programmed cell death mediated by surface-localized immune receptors (Lozano-Torres et al., 2014). Pine wood nematode $B$. xylophilus secreted the potential host mimicry proteins/effectors which closely resemble host pine proteins (Shinya et al., 2013). These proteins might have been acquired by co-evolution of host and parasite and might mimic the host defense systems for compatible and incompatible interactions. A Vap gene, BxVap1 , has also been identified and characterized in B. xylophilus, which might be involved in suppressing defense mechanism of the pine tree (Kang et al., 2012). In addition to co-evolution of genes in the nematodes and their host plants, convergent evolution of effectors from divergent parasites of plants and animals has also occurred. A recent study indicated that $H$. glycines uses HgGLAND18 effector protein for the suppression of both basal and hypersensitive innate immune responses. This protein contains a unique $\mathrm{N}$-terminal domain very similar to that of malaria causing Plasmodium spp. (Noon et al., 2016). Moreover, an effector protein, GrEXPB2 was reported to suppress immunity-associated cell death induced by an extracellular elicitor, necrosis and ethylene-inducing proteinLike Protein (PiNPP) from Phytophthora infestans and NB-LRR immune receptor $\mathrm{Rx}$ (Ali S. et al., 2015). This revealed that apoplastic and cytoplasmic NB-LRR mediated immune responses conditioned by PiNPP and $\mathrm{Rx}$, respectively, are inhibited by GrEXPB2. Furthermore, plant cell death mediated by NB-LRR Bs2 was also suppressed by GrEXPB2 and its cognate effector AvrBs2 (Bs2/AvrBs2) transiently expressed in the leaves of $N$. benthamiana and N. tabacum (Ali S. et al., 2015). However, GrEXPB2 was found to be involved in the elicitation of defense responses in a number of potato and tomato lines. This dual nature of GrEXPB2 function in suppressing and inducing plant resistance is interesting and needs extensive research.

The report from Iberkleid et al. (2013) has provided evidence that Fatty Acid-and Retinol-Binding Protein Mj-FAR-1 aids the process of infection through the suppression of host lipidbased defense mechanisms. They have shown that the tomato roots overexpressing $M j-F A R-1$ led to the down-regulation of JA responsive genes like proteinase inhibitor (Pin2) and $\gamma$-thionin, demonstrating the probable role of Mj-FAR-1 in modulating the lipid based signaling in planta. Very recently in planta silencing of two pioneer genes msp-18 and msp-20 supported lower numbers of $M$. incognita on transgenic egg plants (Shivakumara et al., 2017). Moreover, suppression of these pioneer genes resulted in the down-regulation of cell wall modifying enzymes (CWME), i.e., Mi-pg-1 and Mi-pel, in females developing in the best transgenic events as compared to the control. This suggests that transcriptional repression of CWME genes due to silencing of msp-18 and msp-20 could protect the plants against the root knot nematode. Mantelin et al. (2015) provided the insights into the involvement of effectors in activation and suppression of host innate immune responses. However, mostly the effectors are reported to target host defense and nuclear functions to establish NFSs in plant roots.

\section{NEMATODE EFFECTORS RECRUIT PLANT GENES FOR A COMPATIBLE INTERACTION}

PPNs use a variety of effectors to induce NFSs and to maintain the function of these feeding sites. We have already discussed different effectors that are involved in these processes. However, during the recent years, many plant genes have been identified 
as being manipulated by the nematodes for the above purposes while it is still unknown which effectors might be involved in the expressional modulation of these genes.

In addition to injecting their own CWDEs and related proteins, nematodes also activate the CWDEs of plants, such as endo-1,4- $\beta$-glucanases, cellulases, pectate lyases, expansins, and tubulins which facilitate the nematodes to modify and degrade plant cell walls to support the nematode invasion and ultimate establishment of NFSs (Goellner et al., 2001; Wieczorek et al., 2006, 2008, 2014; Szakasits et al., 2009; Barcala et al., 2010; Banora et al., 2011). The knockout mutants of two endo-1,4- $\beta$ glucanases, which were highly up-regulated in syncytia, revealed less susceptibility of Arabidopsis in response to the beet cyst nematode (Wieczorek et al., 2008). This reveals that in addition to their own pectate lyases, nematodes require plant pectate lyases to develop NFSs. The expression of expansin family genes was also reported to be activated in syncytia induced by the beet cyst nematode in Arabidopsis (Wieczorek et al., 2006). Similarly, the expression of pectate lyase like genes PLL18 (At3g27400) and PLL19 (At4g24780) was found to be induced by H. schachtii and $M$. incognita in syncytia and giant cells, respectively (Wieczorek et al., 2014). Knock out T-DNA insertion mutants of both of these genes demonstrated their significant role in the development of syncytia but not in case of giant cells. Additional plant genes that are strongly up-regulated in nematode NFSs include an ATPase gene from Arabidopsis, At1g64110, which was highly upregulated in syncytia induced by $H$. schachtii on Arabidopsis roots (Ali et al., 2013b). The knocking down of this gene in syncytia supported lower numbers of nematodes. The At1g64110 belongs to the meiotic clade of AAA proteins which also include Vps4, katanin, spastin, and MSP1 (Ammelburg et al., 2006). These AAA proteins are known to be involved in remodeling of membranes and shaping of their protein content which are very important components in the development of NFSs (Ali et al., 2013b).

Establishment of NFSs requires hyper-metabolic conditions for morpho-physiological changes occurring in the initial syncytial cells or young giant cells in the early time points of nematode infections. This requires a lot of energy by the plants to execute these processes needing more and more reservoirs of amino acids which are translocated by amino acid transporters. The beet cyst nematode, H. schachtii, was able to induce the expression of these transporters in syncytia. It was reported that amino acid transporters are important for the development of NFSs in Arabidopsis (Elashry et al., 2013). Moreover, the WRKY23 transcription factor was up-regulated and involved in the establishment of syncytia induced by $H$. schachtii in Arabidopsis roots (Grunewald et al., 2008). Recently, auxin response transcription factors have been found to be upregulated in the syncytia induced by $H$. schachtii suggesting their role in determining the maximum size along with maintaining the functional phenotype of mature syncytia; however, their proper function is still to be investigated (Hewezi et al., 2014). Similarly, a study demonstrated that $M$. incognita infection resulted in the up-regulation of Arabidopsis F-box/Kelch-Repeat coding gene At2g44130 in giant cells (Curtis et al., 2013). This gene was found to be important for nematode development on plant roots as its knock out mutant supported a lower number of nematodes in addition to a more susceptible line overexpressing At2g44130 protein. F-box proteins are crucial for the precise deactivation of cellular regulatory proteins through the process of ubiquitination. This suggested that PPNs induce host F-box proteins to ubiquitinate and degrade plant regulatory proteins, i.e., transcription factors, involved in the process of resistance.

Transcriptomes of NFSs compared with control roots confirmed the expression of plant genes related to high metabolic activity in the NFSs (Gheysen and Fenoll, 2002; Puthoff et al., 2003; Bar-Or et al., 2005; Hammes et al., 2005; Jammes et al., 2005; Szakasits et al., 2009). Genes coding for starch synthases, myo-inositol phosphate oxygenase, sucrose transporters, myo-inositol oxygenases, and UDP-glucose dehydrogenase (UGD) related to high metabolic activity are preferentially up-regulated in NFSs during compatible interactions (Hofmann and Grundler, 2007; Hofmann et al., 2007, 2008, 2009a,b, 2010; Afzal et al., 2009; Siddique et al., 2009, 2012; Szakasits et al., 2009; Barcala et al., 2010). An overview of the transcriptome of syncytia induced by $H$. schachtii indicates that At5g56640/myoinositol oxygenase 5 (MIOX5) was the top up-regulated gene followed by AAA + ATPase gene (At1g64110), plant defensin gene Pdf2.1 (At2g02120), profilin 3 (At5g56600), metallothionein 2A (At3g09390), Chlorophyll a-b binding protein 6 (At3g54890), fructose-bisphosphatealdolase 2 FBA2 (At2g21330), Chloroplast stem-loop binding protein (At3g63140), and Heavy metal transport/detoxification superfamily protein (At5g66110) (Figure 4; Szakasits et al., 2009). This general overview indicates that most of the genes were involved in the various metabolic pathways of the plants thus rendering hyper-metabolism in syncytia which is quite obvious from the studies of MIOX5 and AAA+ ATPase genes (Siddique et al., 2009; Ali et al., 2013b).

\section{PPNS SUPPRESS HOST GENES INVOLVED IN VARIOUS DEFENSE PATHWAYS}

In addition to recruiting plant genes for compatible interactions, PPNs are smart enough to shut down the defense mechanisms of the plants for establishment of NFSs. Several transcriptome studies of NFSs induced by different PPNs demonstrate the suppression of most of the genes involved in different defense pathways of the plants (Szakasits et al., 2009; Barcala et al., 2010; Kyndt et al., 2012; Ali M. A. et al., 2015). Peroxidases are very important mediators of resistance responses in plants. The transcriptome of syncytia induced by $H$. schachtii demonstrated that out of top hundred most suppressed genes, 14 were coding for peroxidases (Szakasits et al., 2009). This transcriptome revealed the top 10 genes which were downregulated in 5 and 15 days old syncytia. These genes were At3g61430 (plasma membrane intrinsic protein 1A, PIP1A), At1g09090 (RBoHB), At4g15390 (HXXXD-type acyl-transferase family protein), At3g53420 (plasma membrane intrinsic protein subfamily PIP2), At1g43160 (member of ERF/AP2 transcription factor family, RAP2.6), At3g22600 (Lipid transfer protein), At2g32270 (zinc transporter, ZIP3), At5g59090 (subtilase 4.12, SBT4.12), At1g61590 (putative receptor-like cytoplasmic kinase), 


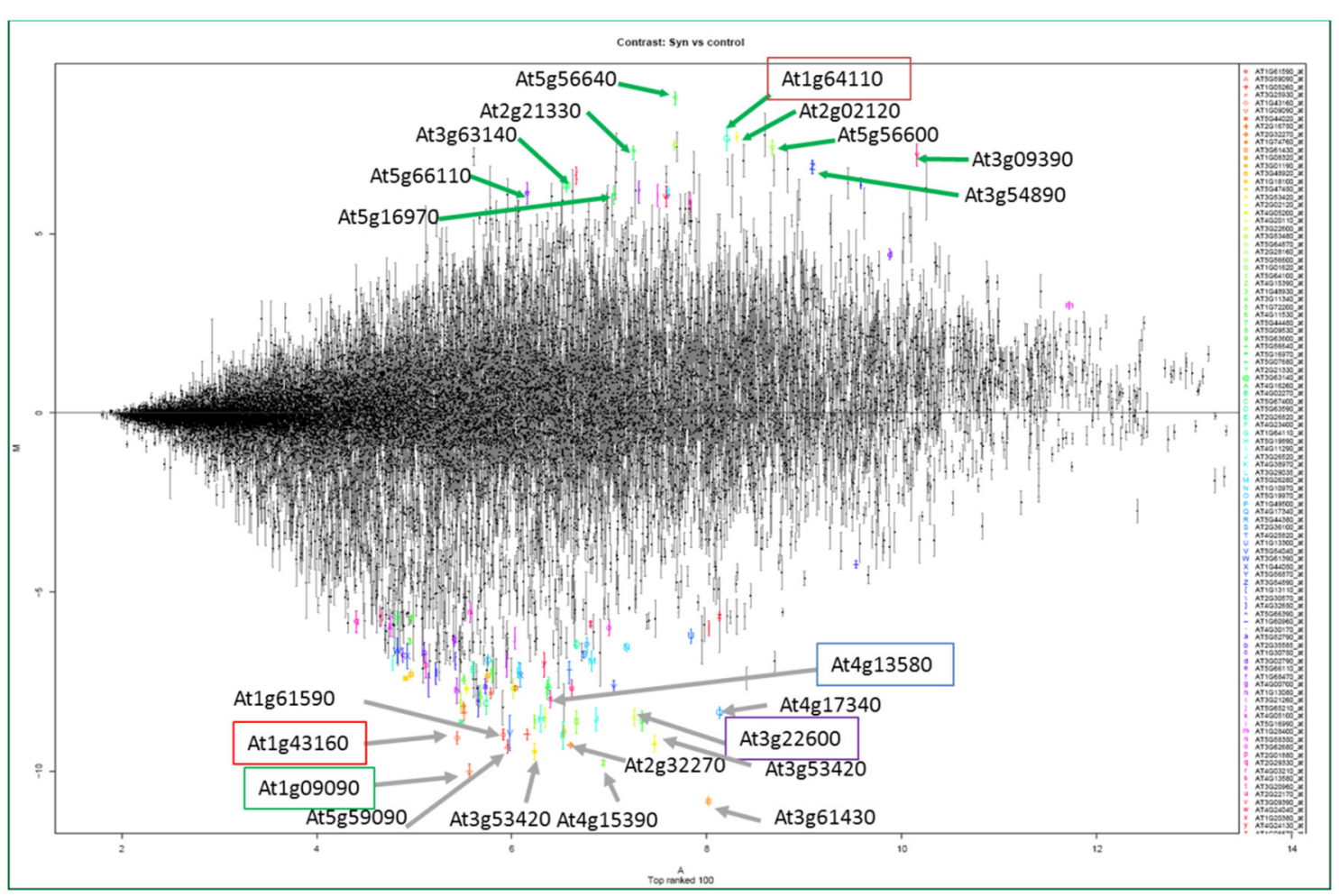

FIGURE 4 | The structure of the transcriptome of syncytia from Szakasits et al. (2009). Strongly up-regulated (above the line) and down-regulated (below the line) genes shown by different colors and letters in the transcriptome of syncytia induced by $\mathrm{H}$. schachtii in Arabidopsis roots. The highlighted genes have been characterized in response to H. schachtii infection in Arabidopsis (Ali, 2012; Ali et al., 2013a,b, 2014).

and At3g13580 (disease resistance responsive gene). Most of them are associated with defense related pathways of the plants (Figure 4; Szakasits et al., 2009).

Ethylene response factors are also crucial for transcription regulation of defense related genes (Licausi et al., 2013). Ethylene transcription factor, AtRAP2.6, was one of the most suppressed genes in the syncytia induced by $H$. schachtii in Arabidopsis. The constitutive expression of this gene led to resistance against the beet cyst nematode (Ali et al., 2013a). Moreover, this decrease in susceptibility was coupled with increased expression of JA marker genes and callose deposition. Similarly, WRKY transcription factors are very important modulators of resistance response of plants against biotic and abiotic stresses. WRKY33 is the most important player in the activation of camalexin synthesis pathway in plants against the invading pathogens. It was the most downregulated gene among the WRKY transcription factors. Syncytia specific overexpression of WRKY33 and constitutive expression of MKK4 led to incompatible plant nematode interaction in the Arabidopsis-beet cyst nematode model system (Ali et al., 2014). However, knockout mutants of WRKY33 and PAD3 resulted in enhanced susceptibility as compared to control which demonstrated that nematodes shut down the phytoalexin pathways for successful parasitism. In addition to WRKY33, other defense responsive WRKYs such as WRKY6, WRKY11, WRKY17, and WRKY25 were also down-regulated in syncytia, which suggests that nematodes have specialized strategies to suppress plant transcription factors that are involved in resistance responses (Ali et al., 2014).

\section{PPNS MANIPULATE RNA SILENCING PATHWAYS FOR SUCCESSFUL PARASITISM}

RNA silencing pathways are very important modulators of plant growth, development, and responses to biotic and abiotic stresses. A variety of RNA silencing pathways are involved in plant defense responses against invading pathogens such as viruses and bacteria. Walsh et al. (2017) recently demonstrated the importance of these pathways in plant nematode interactions. When viral RNA suppressors were expressed in tobacco plants, they became more susceptible to $M$. incognita. MicroRNAs (miRNAs) are one of the key players involved in RNA silencing pathways of the plants. These miRNAs are involved in the regulation of a variety of plant processes ranging from seed development to plant responses against biotic and abiotic stresses (Sunkar, 2012). It has been reported that the Arabidopsis miRNA396 interacts with GRF1/GRF3 transcriptios factors to regulate the reprogramming of root cells during beet cyst nematode infection (Hewezi et al., 2012).

Twenty miRNAs were found to have diverse expression patterns between susceptible and resistant soybean lines during 
the interaction with $H$. glycines (Li et al., 2012). Similarly, a recent study confirmed that the majority of miRNAs from tomato roots infected with $M$. incognita were significantly upregulated during a susceptible interaction (Kaur et al., 2017). Moreover, a negative correlation was observed in the upregulated miRNAs (miR156, miR159, miR164, and miR396) and their target transcription factors, SBP, GAMYB-like, NAC, and GRF1, respectively. It suggests that miRNAs play a vital role in the regulation of transcription factors involved in plant development and resistance to favor compatible plant-nematode interactions at molecular level.

\section{THE NEMATODES INFLUENCE ROS PATHWAYS FOR COMPATIBLE INTERACTION}

Reactive Oxygen Species (ROS) are a byproduct of metabolism and can be destructive for the cells. Therefore, these reactive molecules have to be detoxified by various enzymes. However, ROS are also signaling molecules. Plants produce ROS to activate their defense responses against the pathogens and to stimulate programmed cell death (PCD) or the hypersensitive response (HR) to detain and kill the invading pathogens at the site of infection. The production of ROS is highly dependent on the concentration of different hormones, especially SA, which is the main stimulator of $\mathrm{HR}$ at the site of pathogen invasion and surrounding cells (Durner et al., 1997; Durrant and Dong, 2004). Production of ROS is one of the earliest responses of the plants to infections (Torres, 2006). Kandoth et al. (2011) showed up-regulation of various genes involved in ROS biosynthesis in $H$. glycines resistant lines harboring the Rhg1 gene which confers resistance against soybean cyst nematodes. Similarly, Beneventi et al. (2013) suggested that in a resistant line of soybean, auxin-induced ROS production is positively correlated with $\mathrm{Ca}^{2+}$ conductance across the cell membranes, possibly with the participation of plant annexins in the terminal growth points of the roots. Furthermore, DELLA-like proteins were found to be involved in auxin regulated ROS signaling, which controls resistance responses of resistant soybean plants against parasitic nematodes (Beneventi et al., 2013).

Nematodes have specialized enzymes called superoxide dismutases (SODs) in their secretions to detoxify and minimize the effects of ROS. Several genes have been discovered, which code for SODs in root knot nematodes (Bellafiore et al., 2008; Roze et al., 2008). Nematodes also scavenge ROS by using enzymes such as ascorbate peroxidases, cytochrome Cperoxidases, catalases, thioredoxins, and glutathione peroxidases, which protect cells from ROS-catalyzed damage (Campos et al., 2005; Bellafiore et al., 2008).

Most of the times, synthesis of ROS is regulated by SA accumulation in the cell which leads to PCD in response to pathogen infection in plants (Draper, 1997; Overmyer et al., 2003). However, ROS production through SA pathway antagonizes with that of the Respiratory Burst Oxidase Homologs $(\mathrm{RBOH})$ dependent pathway in Arabidopsis (Torres et al., 2005). A recent study demonstrated that nematodes are able to manipulate the plant ROS pathway to develop a compatible interaction with the plant roots (Siddique et al., 2014). In this study, it was reported that $H$. schachtii stimulates the Arabidopsis $\mathrm{RBOH}$ genes $R B o h F$ and $R B o h D$ to produce ROS that in contrast to defense induction results in the inhibition of PCD to promote establishment of the nematodes on plant roots. Similarly, the cloning, expression and functional analysis of a peroxidase gene belonging to the peroxiredoxin family from $G$. rostochiensis revealed that the peroxiredoxins could play an important role in protection of the parasite from plant defense responses by a series of redox reactions (Robertson et al., 2000).

\section{EFFECTORS MEDIATE POST-TRANSLATIONAL MODIFICATIONS FOR COMPATIBLE INTERACTIONS}

In addition to various other strategies, PPNs modulate posttranslational modifications (PTMs) in plants by interacting with plant proteins involved in various PTM pathways. These modifications include phosphorylation (Hewezi et al., 2015), ubiquitination (Chronis et al., 2013), glycosylation (Chen S. et al., 2015), proteolysis (Lozano-Torres et al., 2014; Noon et al., 2016), and histone modifications (Jones et al., 2009). Phosphorylation and dephosphorylation are very important PTMs and are the main players of signaling cascades in living organisms. Hewezi et al. (2015) reported the involvement of an effector protein (10A07) in targeting the plant transcriptional machinery for its promotion of parasitism. They further demonstrated that the 10A07 protein physically interacts with Interacting Plant Kinase (IPK) and the IAA16 transcription factor. This results in phosphorylation of the $10 \mathrm{~A} 07$ protein at serine number 144 and 231 to mediate its trafficking from the cytoplasm to the nucleus (Hewezi et al., 2015). It has been shown that CLV2 and CORYNE (CRN), members of the receptor kinase family, are required for nematode CLE signaling and are important for both the successful nematode infection and the formation and maintenance of nematode-induced syncytia (Replogle et al., 2011). Recently, it was demonstrated that two additional receptors, CLV1 and Receptor-Like Protein Kinase 2/TOADSTOOL2 (RPK2), are able to transduce the CLV3 signal independent of CLV2/CRN for the maintenance of shoot apical meristem in Arabidopsis (Replogle et al., 2013). Both of these receptors also play an important role in nematode CLE perception.

Ubiquitination involves the attachment of ubiquitin to a substrate protein in eukaryotic cells. The ubiquitin extension protein was found to be only prevalent in cyst nematodes (Tytgat et al., 2004). In total, 12 Hs-Ubil homologous were found in cysts of $H$. schachtii but none from root-knot nematodes. It indicated that the short C-terminal polypeptide of Hs-UBI1 could be important for the development of the syncytium but not in giant cell formation (Tytgat et al., 2004). Likewise, a ubiquitin carboxyl extension protein, GrUBCEP12 secreted by the potato cyst nematode $G$. rostochiensis was reported to be processed into free ubiquitin and a CEP12 peptide to develop successful parasitism (Chronis et al., 2013). RNAi mediated silencing of GrUBCEP12 
in plants displayed reduction of susceptibility in potato plants against $G$. rostochiensis. This revealed that ubiquitination is an important PTM which promotes compatible plant-nematode interaction.

Glycosylation is a complex PTM that involves the addition of carbohydrate molecules to a protein through covalent bonding. This modification significantly affects the biophysical properties of proteins. A multidomain effector protein from G. rostochiensis (GrCLE1) was processed into 12-amino acid arabinosylated glycopeptides through the process of glycosylation (Chen S. et al., 2015). This glycosylation lead to enhanced resistance of this peptide against hydrolytic degradation and high affinity binding to potato CLV2-like receptor (StCLV2) as compared to its non-glycosylated counterpart. This suggested the importance of these PTMs for the promotion of compatible plant nematode interactions. Hewezi (2015) has reviewed the importance and putative role of PTMs like phosphorylation, ubiquitination, glycosylation, proteolysis, and histone modifications in supporting nematode parasitism in plants.

\section{CONCLUSIONS AND OUTLOOK}

As a consequence of enormous yield losses in crop plants imposed by the PPNs, the understanding of plant nematode interactions is becoming of utmost importance. PPNs use multiple strategies to develop successful parasitism in plants. It has now become clear that nematodes, just like other plant pathogens, produce a range of different effectors and suppressors. Omics approaches are being used to characterize the parasitome of different plant pathogenic nematodes at the genomic level (e.g., Eves-van den Akker et al., 2014; Eves-Van Den Akker et al., 2016), the transcriptome level using RNAseq (e.g., Paiva et al., 2013), and the proteome level (e.g., Shinya et al., 2013). Various bioinformatical approaches such as OrthoMCL (Chen et al., 2006) could be very important for computational identification of putative effector proteins (Rutter et al., 2014).

Now that a large number of putative effectors and suppressors are being identified, specific emphasis has to be put on the

\section{REFERENCES}

Abad, P., Gouzy, J., Aury, J. M., Castagnone-Sereno, P., Danchin, E. G. J., Deleury, E., et al. (2008). Genome sequence of the metazoan plant-parasitic nematode Meloidogyne incognita. Nat. Biotechnol. 26, 909-915. doi: 10.1038/nbt.1482

Absmanner, B., Stadler, R., and Hammes, U. Z. (2013). Phloem development in nematode-induced feeding sites: the implications of auxin and cytokinin. Front. Plant Sci. 4:241. doi: 10.3389/fpls.2013.00241

Afzal, A. J., Natarajan, A., Saini, N., Iqbal, M. J., Geisler, M., El Shemy, H. A., et al. (2009). The nematode resistance allele at the rhg1 locus alters the proteome and primary metabolism of soybean roots. Plant Physiol. 151, 1264-1280. doi: $10.1104 /$ pp.109.138149

Ali, M. A. (2012). Induction of Resistance Against Cyst Nematodes by Modifying Gene Expression in Syncytia Doctorate. Vienna: University of Natural Resources and Life Sciences.

Ali, M. A., and Abbas, A. (2016). Analysis of reporter proteins GUS and DsRed driven under the control of CaMV35S promoter in syncytia induced by beet cyst nematode Heterodera schachtii in Arabidopsis roots. Adv. Life Sci. 3, 89-96. identification of their plant targets. Much of that work is being done in the model plant Arabidopsis using all the resources available for this species. In other plant species, virus-induced gene silencing (VIGS) could provide a tool to recognize the important genes required for either pathogenic or symbiotic plant-microbe interactions in plants (Kandoth et al., 2013). Genome editing technologies, especially CRISPR-Cas, could also be used for studying potential functions of effector proteins in plant species. However, results obtained with Arabidopsis may not be easily translated to monocots which include the most important crop plants for human nutrition. To study plantnematode interaction with monocots at the molecular level it will therefore also be important to develop a monocot system such as the rice-Meloidogyne model system (Nguyen et al., 2014).

The interaction between plant pathogenic nematodes and their host plants and especially the induction of specific feeding sites is interesting from a biological point of view. But such knowledge will also have practical applications. On one hand, overexpression or downregulation of plant genes that are downregulated or upregulated in feeding sites could lead to enhanced resistance against nematodes (Klink and Matthews, 2009; Ali, 2012; Ali et al., 2017). On the other hand, knowing the function of nematode effectors might also open a way to counteract these. For these transgenic approaches specific promoters would be needed instead of the widely used CaMV35S promoter (Ali and Abbas, 2016).

\section{AUTHOR CONTRIBUTIONS}

MA conceived, designed, and mainly developed the article; FA contributed in the write up of main body of the review article while HL helped in finalizing the contents and structure of the manuscript, $\mathrm{HB}$ reviewed and finalized the article.

\section{ACKNOWLEDGMENTS}

HB was supported by the Austrian Science Foundation (FWF projects P27323-B22 and P27217-B22). MA was supported by the Higher Education Commission of Pakistan.
Ali, M. A., Abbas, A., Azeem, F., Javed, N., and Bohlmann, H. (2015). Plantnematode interactions: from genomics to metabolomics. Int. J. Agric. Biol. 17, 1071-1082. doi: 10.17957/IJAB/15.0037

Ali, M. A., Abbas, A., Kreil, D. P., and Bohlmann, H. (2013a). Overexpression of the transcription factor RAP2.6 leads to enhanced callose deposition in syncytia and enhanced resistance against the beet cyst nematode Heterodera schachtii in Arabidopsis roots. BMC Plant Biol. 13:47. doi: 10.1186/1471-2229-13-47

Ali, M. A., Azeem, F., Abbas, A., Joyia, F. A., Li, H., and Dababat, A. (2017). Transgenic strategies for enhancement of nematode resistance in plants. Front. Plant Sci. 8:750. doi: 10.3389/fpls.2017.00750

Ali, M. A., Plattner, S., Radakovic, Z., Wieczorek, K., Elashry, A., Grundler, F. M., et al. (2013b). An Arabidopsis ATPase gene involved in nematode-induced syncytium development and abiotic stress responses. Plant J. 74, 852-866. doi: 10.1111/tpj.12170

Ali, M. A., Wieczorek, K., Kreil, D. P., and Bohlmann, H. (2014). The beet cyst nematode Heterodera schachtii modulates the expression of WRKY transcription factors in syncytia to favour its development in Arabidopsis roots. PLoS ONE 9:e102360. doi: 10.1371/journal.pone.0102360 
Ali, S., Magne, M., Chen, S., Cote, O., Stare, B. G., Obradovic, N., et al. (2015). Analysis of putative apoplastic effectors from the nematode, Globodera rostochiensis, and identification of an expansin-like protein that can induce and suppress host defenses. PLoS ONE 10:e115042. doi: 10.1371/journal.pone.0115042

Ammelburg, M., Frickey, T., and Lupas, A. N. (2006). Classification of AAA+ proteins. J. Struct. Biol. 156, 2-11. doi: 10.1016/j.jsb.2006.05.002

Bakhetia, M., Urwin, P. E., and Atkinson, H. J. (2007). qPCR analysis and RNAi define pharyngeal gland cell-expressed genes of Heterodera glycines required for initial interactions with the host. Mol. Plant-Microbe Interact. 20, 306-312. doi: 10.1094/MPMI-20-3-0306

Banora, M. Y., Rodiuc, N., Baldacci-Cresp, F., Smertenko, A., Bleve-Zacheo, T., Mellilo, M. T., et al. (2011). Feeding cells induced by phytoparasitic nematodes require gamma-tubulin ring complex for microtubule reorganization. PLoS Pathog. 7:e1002343. doi: 10.1371/journal.ppat.1002343

Barcala, M., Garcia, A., Cabrera, J., Casson, S., Lindsey, K., Favery, B., et al. (2010). Early transcriptomic events in microdissected Arabidopsis nematode-induced giant cells. Plant J. 61, 698-712. doi: 10.1111/j.1365-313X.2009.04098.x

Bar-Or, C., Kapulnik, Y., and Koltai, H. (2005). A broad characterization of the transcriptional profile of the compatible tomato response to the plant parasitic root knot nematode Meloidogyne javanica. Eur. J. Plant Pathol. 111, 181-192. doi: 10.1007/s10658-004-2134-z

Barras, F., van Gijsegem, F., and Chatterjee, A. K. (1994). Extracellular enzymes and pathogenesis of soft-rot erwinia. Annu. Rev. Phytopathol. 32, 201-234. doi: 10.1146/annurev.py.32.090194.001221

Bekal, S., Niblack, T. L., and Lambert, K. N. (2003). A chorismate mutase from the soybean cyst nematode Heterodera glycines shows polymorphisms that correlate with virulence. Mol. Plant-Microbe Interact. 16, 439-446. doi: 10.1094/MPMI.2003.16.5.439

Bellafiore, S., and Briggs, S. P. (2010). Nematode effectors and plant responses to infection. Curr. Opin. Plant Biol. 13, 442-448. doi: 10.1016/j.pbi.2010.05.006

Bellafiore, S., Shen, Z., Rosso, M.-N., Abad, P., Shih, P., and Briggs, S. P. (2008). Direct identification of the Meloidogyne incognita secretome reveals proteins with host cell reprogramming potential. PLoS Pathog. 4:e1000192. doi: 10.1371/journal.ppat.1000192

Beneventi, M. A., Da Silva, O. B. Jr., De Sa, M. E., Firmino, A. A., De Amorim, R. M., Albuquerque, E. V., et al. (2013). Transcription profile of soybean-rootknot nematode interaction reveals a key role of phythormones in the resistance reaction. BMC Genomics 14:322. doi: 10.1186/1471-2164-14-322

Béra-Maillet, C., Arthaud, L., Abad, P., and Rosso, M.-N. (2000). Biochemical characterization of MI-ENG1, a family 5 endoglucanase secreted by the root-knot nematode Meloidogyne incognita. Eur. J. Biochem. 267, 3255-3263. doi: 10.1046/j.1432-1327.2000.01356.x

Blanchard, A., Esquibet, M., Fouville, D., and Grenier, E. (2005). Ranbpm homologue genes characterised in the cyst nematodes Globodera pallida and Globodera 'mexicana'. Physiol. Mol. Plant Pathol. 67, 15-22. doi: 10.1016/j.pmpp.2005.09.001

Bohlmann, H., and Sobczak, M. (2014). The plant cell wall in the feeding sites of cyst nematodes. Front. Plant Sci. 5:89. doi: 10.3389/fpls.2014. 00089

Burgess, T. L., and Kelly, R. B. (1987). Constitutive and regulated secretion of proteins. Annu. Rev. Cell Biol. 3, 243-293. doi: 10.1146/annurev.cb. 03.110187.001331

Burke, M., Schaff, J. E., Windham, E., Graham, S., Crowell, R., Scholl, E. H., et al. (2015). The plant parasite Pratylenchus coffeaecarries a minimal nematode genome. Nematology 17, 621-637. doi: 10.1163/15685411-00002901

Caillaud, M. C., Dubreuil, G., Quentin, M., Perfus-Barbeoch, L., Lecomte, P., De Almeida Engler, J., et al. (2008). Root-knot nematodes manipulate plant cell functions during a compatible interaction. J. Plant Physiol. 165, 104-113. doi: 10.1016/j.jplph.2007.05.007

Campos, E. G., Jesuino, R. S., Dantas Ada, S., Brigido Mde, M., and Felipe, M. S. (2005). Oxidative stress response in Paracoccidioides brasiliensis. Genet. Mol. Res. 4, 409-429.

Carpentier, J., Grenier, E., Esquibet, M., Hamel, L. P., Moffett, P., ManzanaresDauleux, M. J., et al. (2013). Evolution and variability of Solanum RanGAP2, a cofactor in the incompatible interaction between the resistance protein GPA2 and the Globodera pallida effector Gp-RBP-1. BMC Evol. Biol. 13:87. doi: $10.1186 / 1471-2148-13-87$
Castagnone-Sereno, P., Semblat, J. P., and Castagnone, C. (2009). Modular architecture and evolution of the map-1 gene family in the root-knot nematode Meloidogyne incognita. Mol. Genet. Genomics 282, 547-554. doi: 10.1007/s00438-009-0487-x

Chen, C., Liu, S., Liu, Q., Niu, J., Liu, P., Zhao, J., et al. (2015). An ANNEXIN-like protein from the cereal cyst nematode Heterodera avenae suppresses plant defense. PLOS ONE 10:e0122256. doi: 10.1371/journal.pone. 0122256

Chen, F., MacKey, A. J., Stoeckert, C. J., and Roos, D. S. (2006). OrthoMCLDB: querying a comprehensive multi-species collection of ortholog groups. Nucleic Acids Res. 34, D363-D368. doi: 10.1093/nar/gkj123

Chen, J., Lin, B., Huang, Q., Hu, L., Zhuo, K., and Liao, J. (2017). A novel Meloidogyne graminicola effector, MgGPP, is secreted into host cells and undergoes glycosylation in concert with proteolysis to suppress plant defenses and promote parasitism. PLoS Pathog. 13:e1006301. doi: 10.1371/journal.ppat.1006301

Chen, Q., Rehman, S., Smant, G., and Jones, J. T. (2005). Functional analysis of pathogenicity proteins of the potato cyst nematode Globodera rostochiensis using RNAi. Mol. Plant-Microbe Interact. 18, 621-625. doi: 10.1094/MPMI-18-0621

Chen, S., Lang, P., Chronis, D., Zhang, S., De Jong, W. S., Mitchum, M. G., et al. (2015). In planta processing and glycosylation of a nematode CLAVATA3/ENDOSPERM SURROUNDING REGION-like effector and its interaction with a host CLAVATA2-like receptor to promote parasitism. Plant Physiol. 167, 262-272. doi: 10.1104/pp.114.251637

Chronis, D., Chen, S., Lu, S., Hewezi, T., Carpenter, S. C., Loria, R., et al. (2013). A ubiquitin carboxyl extension protein secreted from a plant-parasitic nematode Globodera rostochiensis is cleaved in planta to promote plant parasitism. Plant J. 74, 185-196. doi: 10.1111/tpj.12125

Consortium (1998). Genome sequence of the nematode C. elegans: a platform for investigating biology. Science 282, 2012-2018.

Cotton, J. A., Lilley, C. J., Jones, L. M., Kikuchi, T., Reid, A. J., Thorpe, P., et al. (2014). The genome and life-stage specific transcriptomes of Globodera pallida elucidate key aspects of plant parasitism by a cyst nematode. Genome Biol. 15:R43. doi: 10.1186/gb-2014-15-3-r43

Curtis, R. H., Pankaj, Powers, S. J., Napier, J., and Matthes, M. C. (2013). The Arabidopsis F-box/Kelch-repeat protein At2g44130 is up-regulated in giant cells and promotes nematode susceptibility. Mol. Plant-Microbe Interact. 26, 36-43. doi: 10.1094/MPMI-05-12-0135-FI

Davis, E. L., Aron, L. M., Pratt, L. H., and Hussey, R. S. (1992). Novel immunization procedures used to develop monoclonal-antibodies that bind to specific structures in Meloidogyne Spp. Phytopathology 82, 1244-1250. doi: 10.1094/Phyto-82-1244

Davis, E. L., Hussey, R. S., and Baum, T. J. (2004). Getting to the roots of parasitism by nematodes. Trends Parasitol. 20, 134-141. doi: 10.1016/j.pt.2004.01.005

Davis, E. L., Hussey, R. S., Baum, T. J., Bakker, J., and Schots, A. (2000). Nematode parasitism genes. Annu. Rev. Phytopathol. 38, 365-396. doi: 10.1146/annurev.phyto.38.1.365

Davis, E. L., Hussey, R. S., Mitchum, M. G., and Baum, T. J. (2008). Parasitism proteins in nematode-plant interactions. Curr. Opin. Plant Biol. 11, 360-366. doi: $10.1016 /$ j.pbi.2008.04.003

Davis, E. L., and Mitchum, M. G. (2005). Nematodes. Sophisticated parasites of legumes. Plant Physiol. 137, 1182-1188. doi: 10.1104/pp.104.054973

de Boer, J. M., Yan, Y. T., Wang, X. H., Smant, G., Hussey, R. S., Davis, E. L., et al. (1999). Developmental expression of secretory beta-1,4-endoglucanases in the subventral esophageal glands of Heterodera glycines. Mol. Plant-Microbe Interact. 12, 663-669. doi: 10.1094/MPMI.1999.12.8.663

de Boer, J. M., Mcdermott, J. P., Davis, E. L., Hussey, R. S., Popeijus, H., Smant, G., et al. (2002). Cloning of a putative pectate lyase gene expressed in the subventral esophageal glands of Heterodera glycines. J. Nematol. 34, 9-11.

De Meutter, J., Vanholme, B., Bauw, G., Tytgat, T., Gheysen, G., and Gheysen, G. (2001). Preparation and sequencing of secreted proteins from the pharyngeal glands of the plant parasitic nematode Heterodera schachtii. Mol. Plant Pathol. 2, 297-301. doi: 10.1046/j.1464-6722.2001.00078.x

Decraemer, W., and Hunt, D. J. (2006). "Structure and classification," in Plant Nematology, eds R. N. Perry and M. Moens (Oxfordshire: CABI1), 3-32.

Dieterich, C., Clifton, S. W., Schuster, L. N., Chinwalla, A., Delehaunty, K., Dinkelacker, I., et al. (2008). The Pristionchus pacificus genome provides 
a unique perspective on nematode lifestyle and parasitism. Nat. Genet. 40, 1193-1198. doi: 10.1038/ng.227

Ding, X., Shields, J., Allen, R., and Hussey, R. S. (2000). Molecular cloning and characterisation of a venom allergen AG5-like cDNA from Meloidogyne incognita. Int. J. Parasitol. 30, 77-81. doi: 10.1016/S0020-7519(99)00165-4

Dinh, P. T. Y., Zhang, L., Mojtahedi, H., Brown, C. R., and Elling, A. A. (2015). Broad Meloidogyne resistance in potato based on RNA interference of effector gene 16D10. J. Nematol. 47, 71-78.

Doyle, E. A., and Lambert, K. N. (2003). Meloidogyne javanica chorismate mutase 1 alters plant cell development. Mol. Plant-Microbe Interact. 16, 123-131. doi: 10.1094/MPMI.2003.16.2.123

Draper, J. (1997). Salicylate, superoxide synthesis and cell suicide in plant defence. Trends Plant Sci. 2, 162-165. doi: 10.1016/S1360-1385(97)01030-3

Dubreuil, G., Magliano, M., Deleury, E., Abad, P., and Rosso, M. N. (2007). Transcriptome analysis of root-knot nematode functions induced in the early stages of parasitism. New Phytol. 176, 426-436. doi: 10.1111/j.1469-8137.2007.02181.x

Durner, J., Shah, J., and Klessig, D. F. (1997). Salicylic acid and disease resistance in plants. Trends Plant Sci. 2, 266-274. doi: 10.1016/S1360-1385(97)86349-2

Durrant, W. E., and Dong, X. (2004). Systemic acquired resistance. Annu. Rev. Phytopathol. 42, 185-209. doi: 10.1146/annurev.phyto.42.040803.140421

Elashry, A., Okumoto, S., Siddique, S., Koch, W., Kreil, D. P., and Bohlmann, H. (2013). The AAP gene family for amino acid permeases contributes to development of the cyst nematode Heterodera schachtii in roots of Arabidopsis. Plant Physiol. Biochem. 70, 379-386. doi: 10.1016/j.plaphy.2013.05.016

Endo, B. Y. (1984). Ultrastructure of the esophagus of larvae of the soybean cyst nematode, Heterodera glydnes. Proc. Helminthol. Soc. Wash. 51, 1-24.

Espada, M., Silva, A. C., Eves Van Den Akker, S., Cock, P. J. A., Mota, M., and Jones, J. T. (2016). Identification and characterization of parasitism genes from the pinewood nematode Bursaphelenchus xylophilus reveals a multilayered detoxification strategy. Mol. Plant Pathol. 17, 286-295. doi: 10.1111/mpp.12280

Eves-Van Den Akker, S., Laetsch, D. R., Thorpe, P., Lilley, C. J., Danchin, E. G. J., Da Rocha, M., et al. (2016). The genome of the yellow potato cyst nematode, Globodera rostochiensis, reveals insights into the basis of parasitism and virulence. Genome Biol. 17:124. doi: 10.1186/s13059-016-0985-1

Eves-van den Akker, S., Lilley, C. J., Jones, J. T., and Urwin, P. E. (2014). Identification and characterisation of a hyper-variable apoplastic effector gene family of the potato cyst nematodes. PLoS Pathog. 10:e1004391. doi: 10.1371/journal.ppat.1004391

Fisher, K., and Turner, S. (2007). PXY, a receptor-like kinase essential for maintaining polarity during plant vascular-tissue development. Curr. Biol. 17, 1061-1066. doi: 10.1016/j.cub.2007.05.049

Gao, B., Allen, R., Maier, T., Davis, E. L., Baum, T. J., and Hussey, R. S. (2002). Identification of a new beta-1,4-endoglucanase gene expressed in the esophageal subventral gland cells of Heterodera glycines. J. Nematol. 34, 12-15.

Gao, B. L., Allen, R., Davis, E. L., Baum, T. J., and Hussey, R. S. (2004). Developmental expression and biochemical properties of a beta-1,4endoglucanase family in the soybean cyst nematode, Heterodera glycines. Mol. Plant Pathol. 5, 93-104. doi: 10.1111/j.1364-3703.2004.00209.x

Gao, B. L., Allen, R., Maier, T., Davis, E. L., Baum, T. J., and Hussey, R. S. (2003). The parasitome of the phytonematode Heterodera glycines. Mol. Plant-Microbe Interact. 16, 720-726. doi: 10.1094/MPMI.2003.16.8.720

Geric Stare, B., Fouville, D., Širca, S., Gallot, A., Urek, G., and Grenier, E. (2011). Molecular variability and evolution of the pectate lyase (pel-2) parasitism gene in cyst nematodes parasitizing different Solanaceous plants. J. Mol. Evol. 72, 169-181. doi: 10.1007/s00239-010-9413-4

Gheysen, G., and Fenoll, C. (2002). Gene expression in nematode feeding sites. Annu. Rev. Phytopathol. 40, 191-219. doi: 10.1146/annurev.phyto.40.121201. 093719

Gheysen, G., and Mitchum, M. G. (2011). How nematodes manipulate plant development pathways for infection. Curr. Opin. Plant Biol. 14, 415-421. doi: 10.1016/j.pbi.2011.03.012

Gheysen, G., and Vanmontagu, M. (1995). Plant nematode interactions, a molecular biologists approach. Nematologica 41, 366-384. doi: 10.1163/003925995X00332

Gleason, C., Polzin, F., Habash, S. S., Zhang, L., Utermark, J., Grundler, F. M. W., et al. (2017). Identification of two meloidogyne hapla genes and an investigation of their roles in the plant-nematode interaction. Mol. Plant-Microbe Interact. 30, 101-112. doi: 10.1094/MPMI-06-16-0107-R

Gleason, C. A., Liu, Q. L., and Williamson, V. M. (2008). Silencing a candidate nematode effector gene corresponding to the tomato resistance gene $\mathrm{Mi}-1$ leads to acquisition of virulence. Mol. Plant-Microbe Interact. 21, 576-585. doi: 10.1094/MPMI-21-5-0576

Goellner, M., Smant, G., de Boer, J. M., Baum, T. J., and Davis, E. L. (2000). Isolation of beta-1,4-endoglucanase genes from Globodera tabacum and their expression during parasitism. J. Nematol. 32, 154-165.

Goellner, M., Wang, X. H., and Davis, E. L. (2001). Endo-beta-1,4-glucanase expression in compatible plant-nematode interactions. Plant Cell 13, 2241-2255. doi: 10.1105/tpc.13.10.2241

Grunewald, W., Karimi, M., Wieczorek, K., Van De Cappelle, E., Wischnitzki, E., Grundler, F., et al. (2008). A role for AtWRKY23 in feeding site establishment of plant-parasitic nematodes. Plant Physiol. 148, 358-368. doi: $10.1104 / p p .108 .119131$

Grunewald, W., Van Noorden, G., Van Isterdael, G., Beeckman, T., Gheysen, G., and Mathesius, U. (2009). Manipulation of auxin transport in plant roots during rhizobium symbiosis and nematode parasitism. Plant Cell 21, 2553-2562. doi: 10.1105/tpc.109.069617

Guo, Y. F., Ni, J., Denver, R., Wang, X. H., and Clark, S. E. (2011). Mechanisms of molecular mimicry of plant CLE peptide ligands by the parasitic nematode Globodera rostochiensis. Plant Physiol. 157, 476-484. doi: 10.1104/pp.111.180554

Habash, S. S., Radakovic, Z. S., Vankova, R., Siddique, S., Dobrev, P., Gleason, C., et al. (2017). Heterodera schachtii Tyrosinase-like protein - a novel nematode effector modulating plant hormone homeostasis. Sci. Rep. 7:6874. doi: 10.1038/s41598-017-07269-7

Haegeman, A., Jacob, J., Vanholme, B., Kyndt, T., and Gheysen, G. (2008). A family of GHF5 endo-1,4-beta-glucanases in the migratory plantparasitic nematode Radopholus similis. Plant Pathol. 57, 581-590. doi: 10.1111/j.1365-3059.2007.01814.x

Haegeman, A., Jacob, J., Vanholme, B., Kyndt, T., Mitreva, M., and Gheysen, G. (2009). Expressed sequence tags of the peanut pod nematode Ditylenchus africanus: the first transcriptome analysis of an Anguinid nematode. Mol. Biochem. Parasitol. 167, 32-40. doi: 10.1016/j.molbiopara.2009.04.004

Haegeman, A., Jones, J. T., and Danchin, E. G. J. (2011). Horizontal gene transfer in nematodes: a catalyst for plant parasitism? Mol. Plant-Microbe Interact. 24, 879-887. doi: 10.1094/MPMI-03-11-0055

Haegeman, A., Kyndt, T., and Gheysen, G. (2010). The role of pseudoendoglucanases in the evolution of nematode cell wall-modifying proteins. $J$. Mol. Evol. 70, 441-452. doi: 10.1007/s00239-010-9343-1

Haegeman, A., Mantelin, S., Jones, J. T., and Gheysen, G. (2012). Functional roles of effectors of plant-parasitic nematodes. Gene 492, 19-31. doi: 10.1016/j.gene.2011.10.040

Hamamouch, N., Li, C., Hewezi, T., Baum, T. J., Mitchum, M. G., Hussey, R. S., et al. (2012). The interaction of the novel 30C02 cyst nematode effector protein with a plant beta-1,3-endoglucanase may suppress host defence to promote parasitism. J. Exp. Bot. 63, 3683-3695. doi: 10.1093/jxb/ers058

Hammes, U. Z., Schachtman, D. P., Berg, R. H., Nielsen, E., Koch, W., McIntyre, L. M., et al. (2005). Nematode-induced changes of transporter gene expression in Arabidopsis roots. Mol. Plant-Microbe Interact. 18, 1247-1257. doi: 10.1094/MPMI-18-1247

Henrissat, B. (1991). A classification of glycosyl hydrolases based on amino acid sequence similarities. Biochem. J. 280(Pt 2), 309-316. doi: 10.1042/bj2800309

Henrissat, B., and Davies, G. (1997). Structural and sequence-based classification of glycoside hydrolases. Curr. Opin. Struct. Biol. 7, 637-644. doi: 10.1016/S0959-440X(97)80072-3

Hewezi, T. (2015). Cellular signaling pathways and posttranslational modifications mediated by nematode effector proteins. Plant Physiol. 169, 1018-1026. doi: 10.1104/pp.15.00923

Hewezi, T., Howe, P. J., Maier, T. R., Hussey, R. S., Mitchum, M. G., Davis, E. L., et al. (2010). Arabidopsis spermidine synthase is targeted by an effector protein of the cyst nematode Heterodera schachtii. Plant Physiol. 152, 968-984. doi: 10.1104/pp.109.150557

Hewezi, T., Juvale, P. S., Piya, S., Maier, T. R., Rambani, A., Rice, J. H., et al. (2015). The cyst nematode effector protein $10 \mathrm{~A} 07$ targets and recruits host 
posttranslational machinery to mediate its nuclear trafficking and to promote parasitism in Arabidopsis. Plant Cell 27, 891-907. doi: 10.1105/tpc.114.135327

Hewezi, T., Maier, T. R., Nettleton, D., and Baum, T. J. (2012). The Arabidopsis microRNA396-GRF1/GRF3 regulatory module acts as a developmental regulator in the reprogramming of root cells during cyst nematode infection. Plant Physiol. 159, 321-335. doi: 10.1104/pp.112.193649

Hewezi, T., Piya, S., Richard, G., and Rice, H. J. (2014). Spatial and temporal expression patterns of auxin response transcription factors in the syncytium induced by the beet cyst nematode Heterodera schachtii in Arabidopsis. Mol. Plant Pathol. 15, 730-736. doi: 10.1111/mpp.12121

Hofmann, J., El Ashry Ael, N., Anwar, S., Erban, A., Kopka, J., and Grundler, F. (2010). Metabolic profiling reveals local and systemic responses of host plants to nematode parasitism. Plant J. 62, 1058-1071. doi: 10.1111/j.1365-313X.2010.04217.x

Hofmann, J., and Grundler, F. M. W. (2007). How do nematodes get their sweets? Solute supply to sedentary plant-parasitic nematodes. Nematology 9, 451-458. doi: 10.1163/156854107781487305

Hofmann, J., Hess, P. H., Szakasits, D., Blochl, A., Wieczorek, K., DaxbockHorvath, S., et al. (2009a). Diversity and activity of sugar transporters in nematode-induced root syncytia. J. Exp. Bot. 60, 3085-3095. doi: 10.1093/jxb/erp138

Hofmann, J., Kolev, P., Kolev, N., Daxbock-Horvath, S., and Grundler, F. M. W. (2009b). The Arabidopsis thaliana sucrose transporter gene AtSUC4 is expressed in Meloidogyne incognita-induced root galls. J. Phytopathol. 157, 256-261. doi: 10.1111/j.1439-0434.2008.01468.x

Hofmann, J., Szakasits, D., Blochl, A., Sobczak, M., Daxbock-Horvath, S., Golinowski, W., et al. (2008). Starch serves as carbohydrate storage in nematode-induced syncytia. Plant Physiol. 146, 228-235. doi: 10.1104/pp.107.107367

Hofmann, J., Wieczorek, K., Blochl, A., and Grundler, F. M. W. (2007). Sucrose supply to nematode-induced syncytia depends on the apoplasmic and symplasmic pathways. J. Exp. Bot. 58, 1591-1601. doi: 10.1093/jxb/erl285

Huang, G. Z., Allen, R., Davis, E. L., Baum, T. J., and Hussey, R. S. (2006a). Engineering broad root-knot resistance in transgenic plants by RNAi silencing of a conserved and essential root-knot nematode parasitism gene. Proc. Natl. Acad. Sci. U.S.A. 103, 14302-14306. doi: 10.1073/pnas.0604698103

Huang, G. Z., Dong, R. H., Allen, R., Davis, E. L., Baum, T. J., and Hussey, R. S. (2006b). A root-knot nematode secretory peptide functions as a ligand for a plant transcription factor. Mol. Plant-Microbe Interact. 19, 463-470. doi: 10.1094/MPMI-19-0463

Huang, G. Z., Gao, B. L., Maier, T., Allen, R., Davis, E. L., Baum, T. J., et al. (2003). A profile of putative parasitism genes expressed in the esophageal gland cells of the root-knot nematode Meloidogyne incognita. Mol. Plant-Microbe Interact. 16, 376-381. doi: 10.1094/MPMI.2003.16.5.376

Hussey, R. S. (1989). Disease-inducing secretions of plant-parasitic nematodes. Annu. Rev. Phytopathol. 27, 123-141. doi: 10.1146/annurev.py.27.090189. 001011

Hussey, R. S., Davis, E. L., and Baum, T. J. (2002). Secrets in secretions: genes that control nematode parasitism of plants. Braz. J. Plant Physiol. 14. doi: 10.1590/S1677-04202002000300002

Iberkleid, I., Vieira, P., De Almeida Engler, J., Firester, K., Spiegel, Y., and Horowitz, S. B. (2013). Fatty acid-and retinol-binding protein, Mj-FAR1 induces tomato host susceptibility to root-knot nematodes. PLoS ONE 8:e64586. doi: 10.1371/journal.pone.0064586

Jacob, J., Vanholme, B., Haegeman, A., and Gheysen, G. (2007). Four transthyretin-like genes of the migratory plant-parasitic nematode Radopholus similis: members of an extensive nematode-specific family. Gene 402, 9-19. doi: 10.1016/j.gene.2007.07.015

Jammes, F., Lecomte, P., De Almeida-Engler, J., Bitton, F., Martin-Magniette, M. L., Renou, J. P., et al. (2005). Genome-wide expression profiling of the host response to root-knot nematode infection in Arabidopsis. Plant J. 44, 447-458. doi: 10.1111/j.1365-313X.2005.02532.x

Jaouannet, M., Magliano, M., Arguel, M. J., Gourgues, M., Evangelisti, E., Abad, P., et al. (2013). The root-knot nematode calreticulin Mi-CRT is a key effector in plant defense suppression. Mol. Plant-Microbe Interact. 26, 97-105. doi: 10.1094/MPMI-05-12-0130-R

Jaouannet, M., Perfus-Barbeoch, L., Deleury, E., Magliano, M., Engler, G., Vieira, P., et al. (2012). A root-knot nematode-secreted protein is injected into giant cells and targeted to the nuclei. New Phytol. 194, 924-931. doi: 10.1111/j.1469-8137.2012.04164.x

Jaouannet, M., and Rosso, M. N. (2013). Effectors of root sedentary nematodes target diverse plant cell compartments to manipulate plant functions and promote infection. Plant Signal. Behav. 8:e25507. doi: 10.4161/psb.25507

Jaubert, S., Ledger, T. N., Laffaire, J. B., Piotte, C., Abad, P., and Rosso, M. N. (2002). Direct identification of stylet secreted proteins from root-knot nematodes by a proteomic approach. Mol. Biochem. Parasitol. 121, 205-211. doi: 10.1016/S0166-6851(02)00034-8

Jaubert, S., Milac, A. L., Petrescu, A. J., De Almeida-Engler, J., Abad, P., and Rosso, M. N. (2005). In planta secretion of a calreticulin by migratory and sedentary stages of root-knot nematode. Mol. Plant-Microbe Interact. 18, 1277-1284. doi: 10.1094/MPMI-18-1277

Jones, J., Furlanetto, C., and Kikuchi, T. (2005). Horizontal gene transfer from bacteria and fungi as a driving force in the evolution of plant parasitism in nematodes. Nematology 7, 641-646. doi: 10.1163/156854105775142919

Jones, J. T., Furlanetto, C., Bakker, E., Banks, B., Blok, V., Chen, Q., et al. (2003). Characterization of a chorismate mutase from the potato cyst nematode Globodera pallida. Mol. Plant Pathol. 4, 43-50. doi: 10.1046/j.1364-3703.2003.00140.x

Jones, J. T., Kumar, A., Pylypenko, L. A., Thirugnanasambandam, A., Castelli, L., Chapman, S., et al. (2009). Identification and functional characterization of effectors in expressed sequence tags from various life cycle stages of the potato cyst nematode Globodera pallida. Mol. Plant Pathol. 10, 815-828. doi: 10.1111/j.1364-3703.2009.00585.x

Jones, M. G. K. (1981). Host cell responses to endoparasitic nematode attack: structure and function of giant cells and syncytia. Ann. Appl. Biol. 97, 353-372. doi: 10.1111/j.1744-7348.1981.tb05122.x

Jones, M. G. K., and Payne, H. L. (1978). Early stage of nematode-induced giant-cell formation in roots of Impatiens balsamina. J. Nematol. 10, 70-84.

Kandoth, P. K., Heinz, R., Yeckel, G., Gross, N. W., Juvale, P. S., Hill, J., et al. (2013). A virus-induced gene silencing method to study soybean cyst nematode parasitism in Glycine max. BMC Res. Notes 6:255. doi: 10.1186/1756-0500-6-255

Kandoth, P. K., Ithal, N., Recknor, J., Maier, T., Nettleton, D., Baum, T. J., et al. (2011). The soybean Rhgl locus for resistance to the soybean cyst nematode Heterodera glycines regulates the expression of a large number of stressand defense-related genes in degenerating feeding cells. Plant Physiol. 155, 1960-1975. doi: 10.1104/pp.110.167536

Kang, J. S., Koh, Y. H., Moon, Y. S., and Lee, S. H. (2012). Molecular properties of a venom allergen-like protein suggest a parasitic function in the pinewood nematode Bursaphelenchus xylophilus. Int. J. Parasitol. 42, 63-70. doi: 10.1016/j.ijpara.2011.10.006

Kaur, P., Shukla, N., Joshi, G., Vijayakumar, C., Jagannath, A., Agarwal, M., et al. (2017). Genome-wide identification and characterization of miRNAome from tomato (Solanum lycopersicum) roots and root-knot nematode (Meloidogyne incognita) during susceptible interaction. PLOS ONE 12:e175178. doi: 10.1371/journal.pone. 0175178

Kikuchi, T., Cotton, J. A., Dalzell, J. J., Hasegawa, K., Kanzaki, N., McVeigh, P., et al. (2011). Genomic insights into the origin of parasitism in the emerging plant pathogen Bursaphelenchus xylophilus. PLoS Pathog. 7:e1002219. doi: 10.1371/journal.ppat.1002219

Kikuchi, T., Jones, J. T., Aikawa, T., Kosaka, H., and Ogura, N. (2004). A family of glycosyl hydrolase family 45 cellulases from the pine wood nematode Bursaphelenchus xylophilus. FEBS Lett. 572, 201-205. doi: 10.1016/j.febslet.2004.07.039

Kikuchi, T., Shibuya, H., Aikawa, T., and Jones, J. T. (2006). Cloning and characterization of pectate lyases expressed in the esophageal gland of the pine wood nematode Bursaphelenchus xylophilus. Mol. Plant-Microbe Interact. 19, 280-287. doi: 10.1094/MPMI-19-0280

Kikuchi, T., Shibuya, H., and Jones, J. T. (2005). Molecular and biochemical characterization of an endo- $\beta$-1,3-glucanase from the pinewood nematode Bursaphelenchus xylophilus acquired by horizontal gene transfer from bacteria. Biochem. J. 389, 117-125. doi: 10.1042/BJ20042042

Kiyohara, S., and Sawa, S. (2012). CLE signaling systems during plant development and nematode infection. Plant Cell Physiol. 53, 1989-1999. doi: $10.1093 / \mathrm{pcp} / \mathrm{pcs} 136$ 
Klink, V. P., and Matthews, B. F. (2009). Emerging approaches to broaden resistance of soybean to soybean cyst nematode as supported by gene expression studies. Plant Physiol. 151, 1017-1022. doi: 10.1104/pp.109.144006

Kovaleva, E. S., Masler, E. P., Skantar, A. M., and Chitwood, D. J. (2004). Novel matrix metalloproteinase from the cyst nematodes Heterodera glycines and Globodera rostochiensis. Mol. Biochem. Parasitol. 136, 109-112. doi: 10.1016/j.molbiopara.2004.03.001

Kudla, U., Milac, A. L., Qin, L., Overmars, H., Roze, E., Holterman, M., et al. (2007). Structural and functional characterization of a novel, host penetration-related pectate lyase from the potato cyst nematode Globodera rostochiensis. Mol. Plant Pathol. 8, 293-305. doi: 10.1111/j.1364-3703.2007.00394.x

Kudla, U., Qin, L., Milac, A., Kielak, A., Maissen, C., Overmars, H., et al. (2005). Origin, distribution and 3D-modeling of Gr-EXPB1, an expansin from the potato cyst nematode Globodera rostochiensis. FEBS Lett. 579, 2451-2457. doi: 10.1016/j.febslet.2005.03.047

Kyndt, T., Haegeman, A., and Gheysen, G. (2008). Evolution of GHF5 endoglucanase gene structure in plant-parasitic nematodes: no evidence for an early domain shuffling event. BMC Evol. Biol. 8:305. doi: 10.1186/1471-2148-8-305

Kyndt, T., Nahar, K., Haegeman, A., De Vleesschauwer, D., Hofte, M., and Gheysen, G. (2012). Comparing systemic defence-related gene expression changes upon migratory and sedentary nematode attack in rice. Plant Biol. 14, 73-82. doi: 10.1111/j.1438-8677.2011.00524.x

Kyndt, T., Vieira, P., Gheysen, G., and De Almeida-Engler, J. (2013). Nematode feeding sites: unique organs in plant roots. Planta 238, 807-818. doi: 10.1007/s00425-013-1923-z

Lambert, K. N., Bekal, S., Domier, L. L., Niblack, T. L., Noel, G. R., and Smyth, C. A. (2005). Selection of Heterodera glycines chorismate mutase-1 alleles on nematode-resistant soybean. Mol. Plant-Microbe Interact. 18, 593-601. doi: 10.1094/MPMI-18-0593

Lambert, K. N., Ferrie, B. J., Nombela, G., Brenner, E. D., and Williamson, V. M. (1999). Identification of genes whose transcripts accumulate rapidly in tomato after root-knot nematode infection. Physiol. Mol. Plant Pathol. 55, 341-348. doi: 10.1006/pmpp.1999.0239

Lee, C., Chronis, D., Kenning, C., Peret, B., Hewezi, T., Davis, E. L., et al. (2011). The novel cyst nematode effector protein $19 \mathrm{C} 07$ interacts with the Arabidopsis auxin influx transporter LAX3 to control feeding site development. Plant Physiol. 155, 866-880. doi: 10.1104/pp.110.167197

Li, X., Wang, X., Zhang, S., Liu, D., Duan, Y., and Dong, W. (2012). Identification of soybean microRNAs involved in soybean cyst nematode infection by deep sequencing. PLoS ONE 7:e39650. doi: 10.1371/journal.pone.0039650

Li, X. D., Zhuo, K., Luo, M., Sun, L. H., and Liao, J. L. (2011). Molecular cloning and characterization of a calreticulin cDNA from the pinewood nematode Bursaphelenchus xylophilus. Exp. Parasitol. 128, 121-126. doi: 10.1016/j.exppara.2011.02.017

Li, Y., Wang, K., Xie, H., Wang, Y. T., Wang, D. W., Xu, C. L., et al. (2015). A nematode calreticulin, Rs-CRT, is a key effector in reproduction and pathogenicity of Radopholus similis. PLoS ONE 10:e0129351. doi: 10.1371/journal.pone.0129351

Licausi, F., Ohme-Takagi, M., and Perata, P. (2013). APETALA2/Ethylene Responsive Factor (AP2/ERF) transcription factors: mediators of stress responses and developmental programs. New Phytol. 199, 639-649. doi: $10.1111 /$ nph.12291

Lin, B., Zhuo, K., Wu, P., Cui, R., Zhang, L. H., and Liao, J. (2013). A novel effector protein, MJ-NULG1a, targeted to giant cell nuclei plays a role in Meloidogyne javanica parasitism. Mol. Plant-Microbe Interact. 26, 55-66. doi: 10.1094/MPMI-05-12-0114-FI

Liu, J., Peng, H., Cui, J., Huang, W., Kong, L., Clarke, J. L., et al. (2016). Molecular characterization of a novel effector expansin-like protein from Heterodera avenae that induces cell death in Nicotiana benthamiana. Sci. Rep. 6:35677. doi: $10.1038 /$ srep 35677

Lozano-Torres, J. L., Wilbers, R. H. P., Gawronski, P., Boshoven, J. C., FinkersTomczak, A., Cordewener, J. H. G., et al. (2012). Dual disease resistance mediated by the immune receptor Cf- 2 in tomato requires a common virulence target of a fungus and a nematode. Proc. Natl. Acad. Sci. U.S.A. 109, 10119-10124. doi: 10.1073/pnas.1202867109

Lozano-Torres, J. L., Wilbers, R. H. P., Warmerdam, S., Finkers-Tomczak, A., Diaz-Granados, A., van Schaik, C. C., et al. (2014). Apoplastic venom allergen-like proteins of cyst nematodes modulate the activation of basal plant innate immunity by cell surface receptors. PLoS Pathog. 10:e1004569. doi: 10.1371/journal.ppat.1004569

Lu, S. W., Chen, S. Y., Wang, J. Y., Yu, H., Chronis, D., Mitchum, M. G., et al. (2009). Structural and functional diversity of CLAVATA3/ESR (CLE)-like genes from the potato cyst nematode Globodera rostochiensis. Mol. Plant-Microbe Interact. 22, 1128-1142. doi: 10.1094/MPMI-22-9-1128

Mantelin, S., Thorpe, P., and Jones, J. T. (2015). Suppression of plant defences by plant-parasitic nematodes. Gene 73, 325-337. doi: 10.1016/bs.abr.2014.12.011

Mitchum, M. G., Hussey, R. S., Baum, T. J., Wang, X., Elling, A. A., Wubben, M., et al. (2013). Nematode effector proteins: an emerging paradigm of parasitism. New Phytol. 199, 879-894. doi: 10.1111/nph.12323

Mitchum, M. G., Wang, X. H., and Davis, E. L. (2008). Diverse and conserved roles of CLE peptides. Curr. Opin. Plant Biol. 11, 75-81. doi: 10.1016/j.pbi.2007.10.010

Nguyen, P. V., Bellafiore, S., Petitot, A.-S., Haidar, R., Bak, A., Abed, A., et al. (2014). Meloidogyne incognita - rice (Oryza sativa) interaction: a new model system to study plant-root-knot nematode interactions in monocotyledons. Rice 7:23. doi: 10.1186/s12284-014-0023-4

Niu, J., Liu, P., Liu, Q., Chen, C., Guo, Q., Yin, J., et al. (2016). Msp40 effector of root-knot nematode manipulates plant immunity to facilitate parasitism. Sci. Rep. 6:19443. doi: 10.1038/srep19443

Noon, J. B., Qi, M., Sill, D. N., Muppirala, U., Eves-Van Den Akker, S., Maier, T. R., et al. (2016). A Plasmodium-like virulence effector of the soybean cyst nematode suppresses plant innate immunity. New Phytol. 212, 444-460. doi: $10.1111 /$ nph.14047

Nyaku, S. T., Sripathi, V. R., Kantety, R. V., Cseke, S. B., Buyyarapu, R., Mc Ewan, R., et al. (2014). Characterization of the reniform nematode genome by shotgun sequencing. Genome 57, 209-221. doi: 10.1139/gen-2014-0019

Oelkers, K., Goffard, N., Weiller, G. F., Gresshoff, P. M., Mathesius, U., and Frickey, T. (2008). Bioinformatic analysis of the CLE signaling peptide family. BMC Plant Biol. 8:1. doi: 10.1186/1471-2229-8-1

Olsen, A. N., and Skriver, K. (2003). Ligand mimicry? Plant-parasitic nematode polypeptide with similarity to CLAVATA3. Trends Plant Sci. 8, 55-57. doi: 10.1016/S1360-1385(03)00003-7

Opperman, C. H., Bird, D. M., Williamson, V. M., Rokhsar, D. S., Burke, M. Cohn, J., et al. (2008). Sequence and genetic map of Meloidogyne hapla: a compact nematode genome for plant parasitism. Proc. Natl. Acad. Sci. U.S.A. 105, 14802-14807. doi: 10.1073/pnas.0805946105

Overmyer, K., Brosche, M., and Kangasjarvi, J. (2003). Reactive oxygen species and hormonal control of cell death. Trends Plant Sci. 8, 335-342. doi: 10.1016/S1360-1385(03)00135-3

Paiva, G., Proença, D. N., Francisco, R., Verissimo, P., Santos, S. S., Fonseca, L., et al. (2013). Nematicidal bacteria associated to pinewood nematode produce extracellular proteases. PLoS ONE 8:e79705. doi: 10.1371/journal.pone.0079705

Patel, N., Hamamouch, N., Li, C. Y., Hewezi, T., Hussey, R. S., Baum, T. J., et al. (2010). A nematode effector protein similar to annexins in host plants. J. Exp. Bot. 61, 235-248. doi: 10.1093/jxb/erp293

Patel, N., Hamamouch, N., Li, C. Y., Hussey, R., Mitchum, M., Baum, T., et al. (2008). Similarity and functional analyses of expressed parasitism genes in Heterodera schachtii and Heterodera glycines. J. Nematol. 40, 299-310.

Peng, H., Parkinson, J., Gao, B.-L., Kong, L.-A., Yu, Q., Huang, W.-K., et al. (2013). Exploring the host parasitism of the migratory plant-parasitic nematode Ditylenchus destuctor by expressed sequence tags analysis. PLoS ONE 8:e69579. doi: 10.1371/journal.pone.0069579

Pereira, F., Hejnol, A., Moreira, C., Fonseca, L., Van Asch, B., Mota, M., et al. (2013). New insights into the phylogeny and worldwide dispersion of two closely related nematode species, Bursaphelenchus xylophilus and Bursaphelenchus mucronatus. PLoS ONE 8:e56288. doi: 10.1371/journal.pone.0056288

Popeijus, M., Blok, V. C., Cardle, L., Bakker, E., Phillips, M. S., Helder, J., et al. (2000). Analysis of genes expressed in second stage juveniles of the potato cyst nematodes Globodera rostochiensis and G. pallida using the expressed sequence tag approach. Nematology 2, 567-574. doi: 10.1163/156854100509358

Postma, W. J., Slootweg, E. J., Rehman, S., Finkers-Tomczak, A., Tytgat, T. O., Van Gelderen, K., et al. (2012). The effector SPRYSEC-19 of Globodera rostochiensis suppresses CC-NB-LRR-mediated disease resistance in plants. Plant Physiol. 160, 944-954. doi: 10.1104/pp.112.200188 
Puthoff, D. P., Nettleton, D., Rodermel, S. R., and Baum, T. J. (2003). Arabidopsis gene expression changes during cyst nematode parasitism revealed by statistical analyses of microarray expression profiles. Plant J. 33, 911-921. doi: 10.1046/j.1365-313X.2003.01677.x

Qin, L., Kudla, U., Roze, E. H. A., Goverse, A., Popeijus, H., Nieuwland, J., et al. (2004). Plant degradation: a nematode expansin acting on plants. Nature 427:30. doi: $10.1038 / 427030$ a

Rai, K. M., Balasubramanian, V. K., Welker, C. M., Pang, M., Hii, M. M., and Mendu, V. (2015). Genome wide comprehensive analysis and web resource development on cell wall degrading enzymes from phyto-parasitic nematodes. BMC Plant Biol. 15:187. doi: 10.1186/s12870-015-0576-4

Rehman, S., Butterbach, P., Popeijus, H., Overmars, H., Davis, E. L., Jones, J. T., et al. (2009a). Identification and characterization of the most abundant cellulases in stylet secretions from Globodera rostochiensis. Phytopathology 99, 194-202. doi: 10.1094/PHYTO-99-2-0194

Rehman, S., Postma, W., Tytgat, T., Prins, P., Qin, L., Overmars, H., et al. (2009b). A secreted SPRY domain-containing protein (SPRYSEC) from the plant-parasitic nematode Globodera rostochiensis interacts with a CC-NB-LRR protein from a susceptible tomato. Mol. Plant-Microbe Interact. 22, 330-340. doi: 10.1094/MPMI-22-3-0330

Replogle, A., Wang, J., Paolillo, V., Smeda, J., Kinoshita, A., Durbak, A., et al. (2013). Synergistic interaction of CLAVATA1, CLAVATA2, and RECEPTORLIKE PROTEIN KINASE 2 in cyst nematode parasitism of Arabidopsis. Mol. Plant-Microbe Interact. 26, 87-96. doi: 10.1094/MPMI-05-12-0118-FI

Replogle, A., Wang, J. Y., Bleckmann, A., Hussey, R. S., Baum, T. J., Sawa, S., et al. (2011). Nematode CLE signaling in Arabidopsis requires CLAVATA2 and CORYNE. Plant J. 65, 430-440. doi: 10.1111/j.1365-313X.2010.04433.x

Robertson, L., Robertson, W. M., Sobczak, M., Helder, J., Tetaud, E., Ariyanayagam, M. R., et al. (2000). Cloning, expression and functional characterisation of a peroxiredoxin from the potato cyst nematode Globedera rostochiensis. Mol. Biochem. Parasitol. 111, 41-49. doi: 10.1016/S0166-6851(00)00295-4

Rosso, M. N., Favery, B., Piotte, C., Arthaud, L., de Boer, J. M., Hussey, R. S., et al. (1999). Isolation of a cDNA encoding a beta-1,4-endoglucanase in the root-knot nematode Meloidogyne incognita and expression analysis during plant parasitism. Mol. Plant-Microbe Interact. 12, 585-591. doi: 10.1094/MPMI.1999.12.7.585

Roze, E., Hanse, B., Mitreva, M., Vanholme, B., Bakker, J., and Smant, G. (2008). Mining the secretome of the root-knot nematode Meloidogyne chitwoodi for candidate parasitism genes. Mol. Plant Pathol. 9, 1-10. doi: $10.1111 / j .1364-3703.2007 .00435 . x$

Rutter, W. B., Hewezi, T., Abubucker, S., Maier, T. R., Huang, G., Mitreva, M., et al. (2014). Mining novel effector proteins from the esophageal gland cells of Meloidogyne incognita. Mol. Plant-Microbe Interact. 27, 965-974. doi: 10.1094/MPMI-03-14-0076-R

Sacco, M. A., Koropacka, K., Grenier, E., Jaubert, M. J., Blanchard, A., Goverse, A., et al. (2009). The cyst nematode SPRYSEC protein RBP-1 elicits Gpa2-and RanGAP2-dependent plant cell death. PLoS Pathog. 5:e1000564. doi: 10.1371/journal.ppat.1000564

Sampedro, J., and Cosgrove, D. J. (2005). The expansin superfamily. Genome Biol. 6:242. doi: 10.1186/gb-2005-6-12-242

Semblat, J. P., Rosso, M. N., Hussey, R. S., Abad, P., and CastagnoneSereno, P. (2001). Molecular cloning of a cDNA encoding an amphidsecreted putative avirulence protein from the root-knot nematode Meloidogyne incognita. Mol. Plant-Microbe Interact. 14, 72-79. doi: 10.1094/MPMI.2001. 14.1 .72

Shibuya, H., and Kikuchi, T. (2008). Purification and characterization of recombinant endoglucanases from the pine wood nematode Bursaphelenchus xylophilus. Biosci. Biotechnol. Biochem. 72, 1325-1332. doi: 10.1271/bbb.70819

Shinya, R., Morisaka, H., Kikuchi, T., Takeuchi, Y., Ueda, M., and Futai, K. (2013). Secretome analysis of the pine wood nematode Bursaphelenchus xylophilus reveals the tangled roots of parasitism and its potential for molecular mimicry. PLoS ONE 8:e67377. doi: 10.1371/journal.pone.0067377

Shivakumara, T. N., Chaudhary, S., Kamaraju, D., Dutta, T. K., Papolu, P. K., Banakar, P., et al. (2017). Host-induced silencing of two pharyngeal gland genes conferred transcriptional alteration of cell wall-modifying enzymes of Meloidogyne incognita vis-à-vis perturbed nematode infectivity in eggplant. Front. Plant Sci. 8:473. doi: 10.3389/fpls.2017.00473
Siddique, S., Endres, S., Atkins, J. M., Szakasits, D., Wieczorek, K., Hofmann, J., et al. (2009). Myo-inositol oxygenase genes are involved in the development of syncytia induced by Heterodera schachtii in Arabidopsis roots. New Phytol. 184, 457-472. doi: 10.1111/j.1469-8137.2009.02981.x

Siddique, S., Matera, C., Radakovic, Z. S., Shamim Hasan, M., Gutbrod, P., Rozanska, E., et al. (2014). Parasitic worms stimulate host NADPH oxidases to produce reactive oxygen species that limit plant cell death and promote infection. Sci. Signal. 7:ra33. doi: 10.1126/scisignal. 2004777

Siddique, S., Radakovic, Z. S., De La Torre, C. M., Chronis, D., Novák, O., Ramireddy, E., et al. (2015). A parasitic nematode releases cytokinin that controls cell division and orchestrates feeding site formation in host plants. Proc. Natl. Acad. Sci. U.S.A. 112, 12669-12674. doi: 10.1073/pnas. 1503657112

Siddique, S., Sobczak, M., Tenhaken, R., Grundler, F. M., and Bohlmann, H. (2012). Cell wall in growths in nematode induced syncytia require UGD2 and UGD3. PLoS ONE 7:e41515. doi: 10.1371/journal.pone.0041515

Smant, G., Stokkermans, J. P. W. G., Yan, Y. T., de Boer, J. M., Baum, T. J., Wang, X. H., et al. (1998). Endogenous cellulases in animals: isolation of beta-1,4-endoglucanase genes from two species of plant-parasitic cyst nematodes. Proc. Natl. Acad. Sci. U.S.A. 95, 4906-4911. doi: 10.1073/pnas.95. 9.4906

Sunkar, R. (ed.). (2012). MicroRNAs in Plant Development and Stress Responses. Berlin; Heidelberg: Springer.

Szakasits, D., Heinen, P., Wieczorek, K., Hofmann, J., Wagner, F., Kreil, D. P., et al. (2009). The transcriptome of syncytia induced by the cyst nematode Heterodera schachtii in Arabidopsis roots. Plant J. 57, 771-784. doi: 10.1111/j.1365-313X.2008.03727.x

Tomalova, I., Iachia, C., Mulet, K., and Castagnone-Sereno, P. (2012). The map-1 gene family in root-knot nematodes, Meloidogyne spp.: a set of taxonomically restricted genes specific to clonal species. PLOS ONE 7:e38656. doi: 10.1371/journal.pone. 0038656

Torres, M. A. (2006). Reactive oxygen species signaling in response to pathogens. Plant Physiol. 141, 373-378. doi: 10.1104/pp.106.079467

Torres, M. A., Jones, J. D. G., and Dangl, J. L. (2005). Pathogen-induced, NADPH oxidase-derived reactive oxygen intermediates suppress spread of cell death in Arabidopsis thaliana. Nat. Genet. 37, 1130-1134. doi: 10.1038/ng1639

Tytgat, T., Vanholme, B., De Meutter, J., Claeys, M., Couvreur, M., Vanhoutte, I., et al. (2004). A new class of ubiquitin extension proteins secreted by the dorsal pharyngeal gland in plant parasitic cyst nematodes. Mol. Plant-Microbe Interact. 17, 846-852. doi: 10.1094/MPMI.2004.17.8.846

Vanholme, B., De Meutter, J., Tytgat, T., Van Montagu, M., Coomans, A., and Gheysen, G. (2004). Secretions of plant-parasitic nematodes: a molecular update. Gene 332, 13-27. doi: 10.1016/j.gene.2004.02.024

Vieira, P., Danchin, E. G., Neveu, C., Crozat, C., Jaubert, S., Hussey, R. S., et al. (2011). The plant apoplasm is an important recipient compartment for nematode secreted proteins. J. Exp. Bot. 62, 1241-1253. doi: 10.1093/jxb/erq352

Vieira, P., Eves-Van Den Akker, S., Verma, R., Wantoch, S., Eisenback, J. D., and Kamo, K. (2015). The Pratylenchus penetrans transcriptome as a source for the development of alternative control strategies: mining for putative genes involved in parasitism and evaluation of in planta RNAi. PLoS ONE 10:e0144674. doi: 10.1371/journal.pone.0144674

Walsh, E., Elmore, J. M., and Taylor, C. G. (2017). Root-knot nematode parasitism suppresses host RNA silencing. Mol. Plant-Microbe Interact. 30, 295-300. doi: 10.1094/MPMI-08-16-0160-R

Wang, G., and Fiers, M. (2009). CLE peptide signaling during plant development. Protoplasma 240, 33-43. doi: 10.1007/s00709-009-0095-y

Wang, J., Hewezi, T., Baum, T. J., Davis, E. L., Wang, X., and Mitchum, M. G. (2010). Trafficking of soybean cyst nematode secreted CLE proteins in plant cells. Phytopathology 100, S132-S132.

Wang, J. Y., Lee, C., Replogle, A., Joshi, S., Korkin, D., Hussey, R., et al. (2010). Dual roles for the variable domain in protein trafficking and host-specific recognition of Heterodera glycines CLE effector proteins. New Phytol. 187, 1003-1017. doi: 10.1111/j.1469-8137.2010.03300.x

Wang, J. Y., Replogle, A., Hussey, R., Baum, T., Wang, X. H., Davis, E. L., et al. (2011). Identification of potential host plant mimics of CLAVATA3/ESR (CLE)like peptides from the plant-parasitic nematode Heterodera schachtii. Mol. Plant Pathol. 12, 177-186. doi: 10.1111/j.1364-3703.2010.00660.x 
Wang, X. H., Meyers, D., Yan, Y. T., Baum, T., Smant, G., Hussey, R., et al. (1999). In planta localization of a beta-1,4-endoglucanase secreted by Heterodera glycines. Mol. Plant-Microbe Interact. 12, 64-67. doi: 10.1094/MPMI.1999.12.1.64

Wang, X. H., Mitchum, M. G., Gao, B. L., Li, C. Y., Diab, H., Baum, T. J., et al. (2005). A parasitism gene from a plant-parasitic nematode with function similar to CLAVATA3/ESR (CLE) of Arabidopsis thaliana. Mol. Plant Pathol. 6, 187-191. doi: 10.1111/j.1364-3703.2005.00270.x

Wang, X. H., Replogle, A., Davis, E. L., and Mitchum, M. G. (2007). The tobacco Cel7 gene promoter is auxin-responsive and locally induced in nematode feeding sites of heterologous plants. Mol. Plant Pathol. 8, 423-436. doi: 10.1111/j.1364-3703.2007.00403.x

Wieczorek, K. (2015). "Cell wall alterations in nematode-infected roots," in Advances in Botanical Research, Vol. 73 Plant Nematode Interactions: A View on Compatible Interrelationships, eds C. Escobar and C. Fenoll (Amsterdam: Academic Press), 61-90. doi: 10.1016/bs.abr.2014.12.002

Wieczorek, K., Elashry, A., Quentin, M., Grundler, F. M. W., Favery, B., Seifert, G. J., et al. (2014). A distinct role of pectate lyases in the formation of feeding structures induced by cyst and root-knot nematodes. Mol. Plant-Microbe Interact. 27, 901-912. doi: 10.1094/MPMI-01-14-0005-R

Wieczorek, K., Golecki, B., Gerdes, L., Heinen, P., Szakasits, D., Durachko, D. M., et al. (2006). Expansins are involved in the formation of nematodeinduced syncytia in roots of Arabidopsis thaliana. Plant J. 48, 98-112. doi: 10.1111/j.1365-313X.2006.02856.x

Wieczorek, K., Hofmann, J., Blochl, A., Szakasits, D., Bohlmann, H., and Grundler, F. M. W. (2008). Arabidopsis endo-1,4-beta-glucanases are involved in the formation of root syncytia induced by Heterodera schachtii. Plant J. 53, 336-351. doi: 10.1111/j.1365-313X.2007.03340.x

Wubben, M. J., Ganji, S., and Callahan, F. E. (2010). Identification and molecular characterization of a beta-1,4-endoglucanase gene (Rr-eng-1) from Rotylenchulus reniformis. J. Nematol. 42, 342-351.

Wubben, M. J., Gavilano, L., Baum, T. J., and Davis, E. L. (2015). Sequence and spatiotemporal expression analysis of CLE-Motif containing genes from the reniform nematode (Rotylenchulus reniformis Linford \& Oliveira). J. Nematol. $47,159-165$.

Wyss, U., and Zunke, U. (1986). Observations on the behaviour of second stage juveniles of Heterodera schachtii inside host roots. Rev. Nématol. 9, 153-165

Xie, J., Li, S., Mo, C., Wang, G., Xiao, X., and Xiao, Y. (2016). A novel Meloidogyne incognita effector Misp12 suppresses plant defense response at latter stages of nematode parasitism. Front. Plant Sci. 7:964. doi: 10.3389/fpls.2016.00964

Yang, Y., Jittayasothorn, Y., Chronis, D., Wang, X., Cousins, P., and Zhong, G. Y. (2013). Molecular characteristics and efficacy of 16D10 siRNAs in inhibiting root-knot nematode infection in transgenic grape hairy roots. PLoS ONE 8:e69463. doi: 10.1371/journal.pone.0069463

Yan, Y. T., Smant, G., and Davis, E. (2001). Functional screening yields a new beta-1,4-endoglucanase gene from Heterodera glycines that may be the product of recent gene duplication. Mol. Plant-Microbe Interact. 14, 63-71. doi: 10.1094/MPMI.2001.14.1.63

Yan, Y. T., Smant, G., Stokkermans, J., Qin, L., Helder, J., Baum, T., et al. (1998). Genomic organization of four beta-1,4-endoglucanase genes in plantparasitic cyst nematodes and its evolutionary implications. Gene 220, 61-70. doi: 10.1016/S0378-1119(98)00413-2

Zhang, L., Davies, L. J., and Elling, A. A. (2015). A Meloidogyne incognita effector is imported into the nucleus and exhibits transcriptional activation activity in planta. Mol. Plant Pathol. 16, 48-60. doi: 10.1111/mpp.12160

Conflict of Interest Statement: The authors declare that the research was conducted in the absence of any commercial or financial relationships that could be construed as a potential conflict of interest.

Copyright (C) 2017 Ali, Azeem, Li and Bohlmann. This is an open-access article distributed under the terms of the Creative Commons Attribution License (CC BY).

The use, distribution or reproduction in other forums is permitted, provided the original author(s) or licensor are credited and that the original publication in this journal is cited, in accordance with accepted academic practice. No use, distribution or reproduction is permitted which does not comply with these terms. 